FIRM REPUTATION AND THE COST OF BANK DEBT

by

Ye Wang

Copyright (C) Ye Wang 2020

A Dissertation Submitted to the Faculty of the

DEPARTMENT OF FINANCE

In Partial Fulfillment of the Requirements

For the Degree of

DOCTOR OF PHILOSOPHY

In the Graduate College

THE UNIVERSITY OF ARIZONA 


\section{THE UNIVERSITY OF ARIZONA GRADUATE COLLEGE}

As members of the Dissertation Committee, we certify that we have read the dissertation prepared by: [Ye Wang], titled: Firm Reputation and the Cost of Bank Debt]

and recommend that it be accepted as fulfilling the dissertation requirement for the Degree of Doctor of Philosophy.

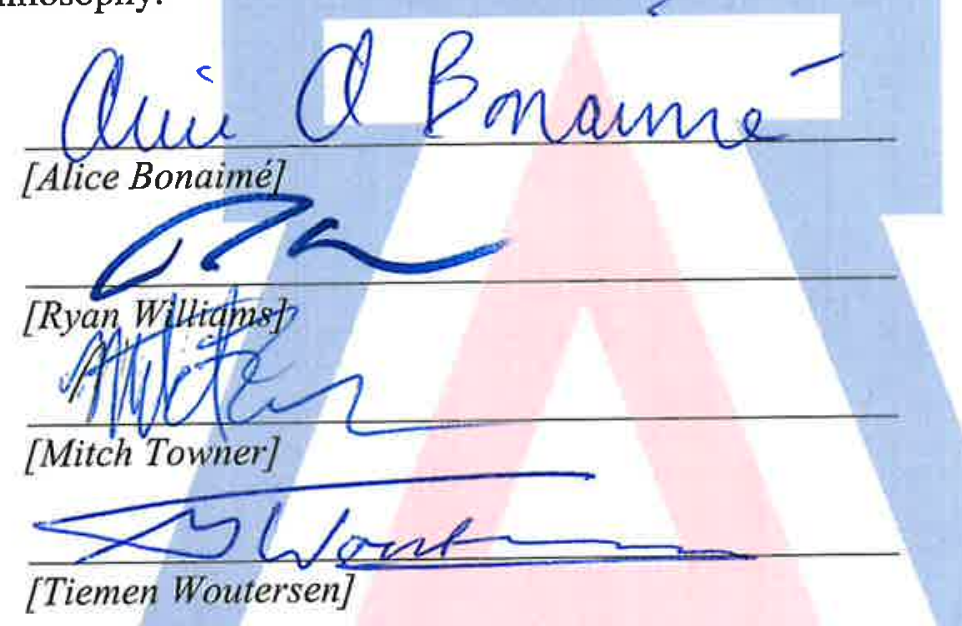

Date: $2 / 25 / 2020$
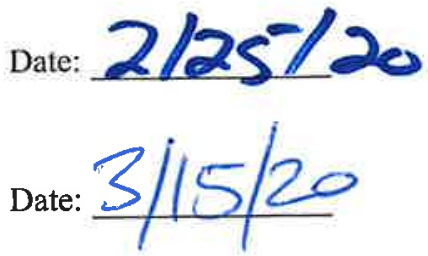

Date: $2 / 25 / 2020$

Final approval and acceptance of this dissertation is contingent upon the candidate's submission of the final copies of the dissertation to the Graduate College.

I hereby certify that I have read this dissertation prepared under my direction and recommend that it be accepted as fulfilling the dissertation requirement.

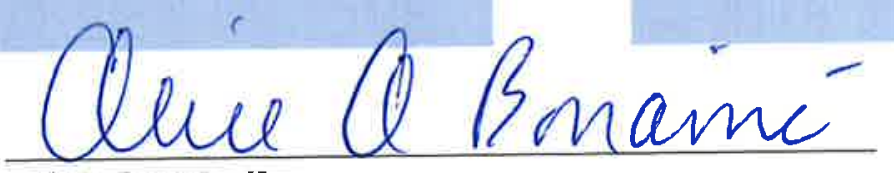

[Alice Bonaimé]

Dissertation Committee Chair [Department of Finance]
Date: $2 / 25 / 2020$

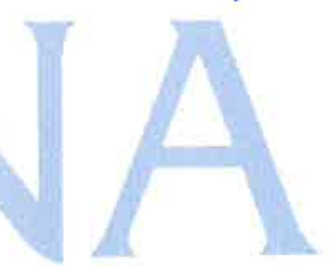




\section{ACKNOWLEDGMENT}

I thank Alice Bonaimé, my dissertation chair, for her enlightening advice and extraordinary patience. I thank my committee members, Mitch Towner, Ryan Williams, and Tiemen Woutersen, for all the time and effort shared in the process of finishing my dissertation. 


\section{DEDICATION}

To:

My Dad, Dr. Shaokun Wang,

Thank you for your support!

I love you! 


\section{Table of Contents}

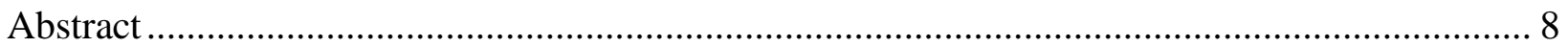

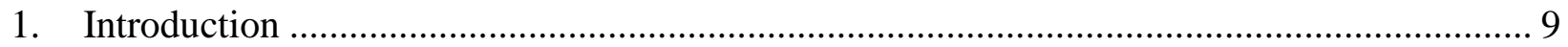

2. Literature review and hypotheses development .......................................................... 14

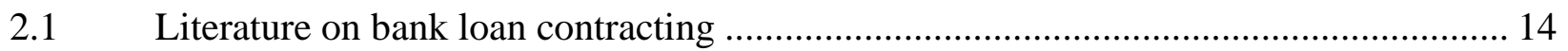

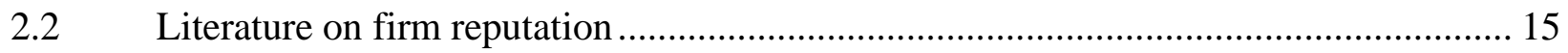

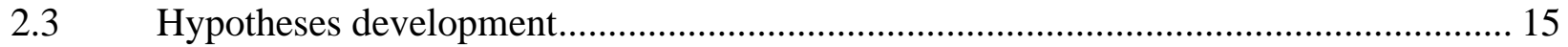

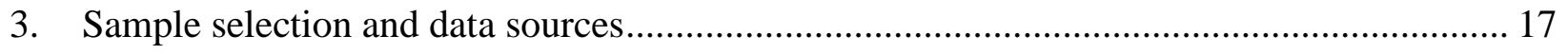

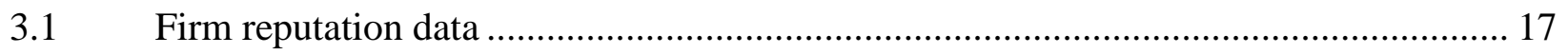

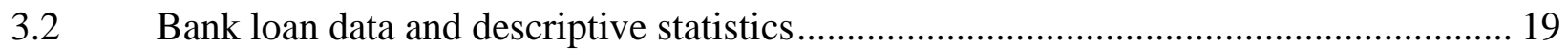

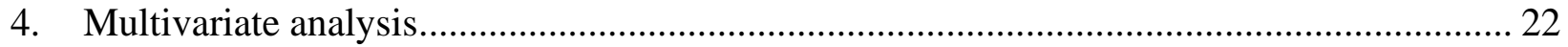

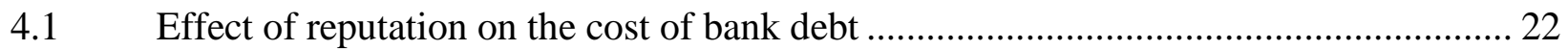

4.2 Effect of reputation on other loan contract terms......................................................... 24

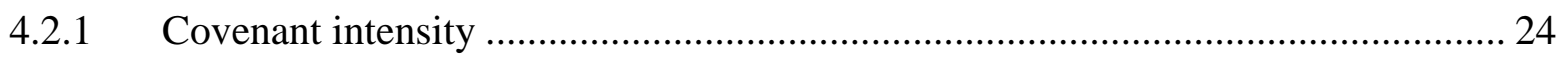

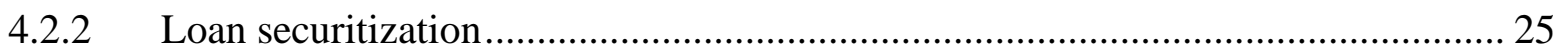

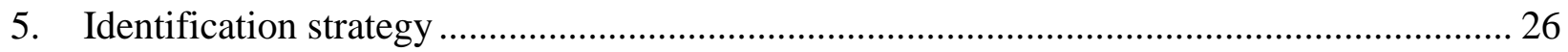

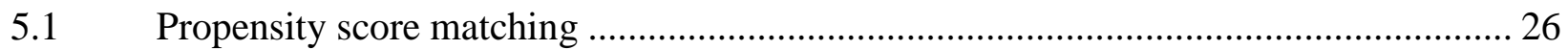

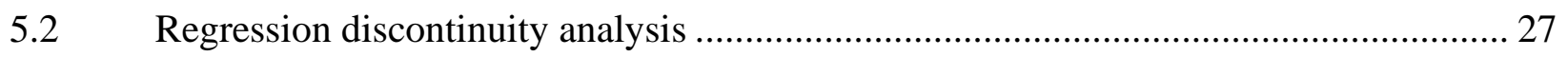

5.3 Removing financial performance from MA scores and ranks ……………................... 30

6. Channels through which reputation affects the cost of bank debt ........................................... 31

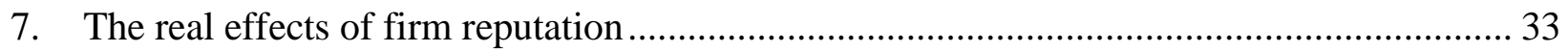

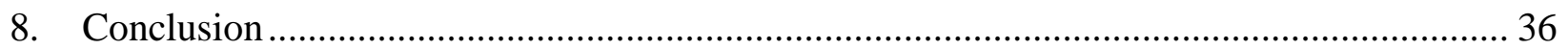

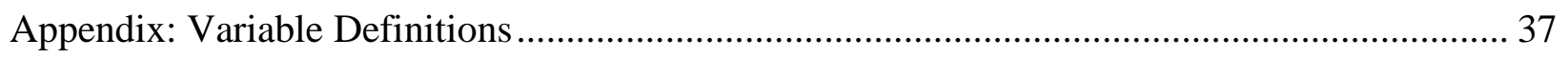

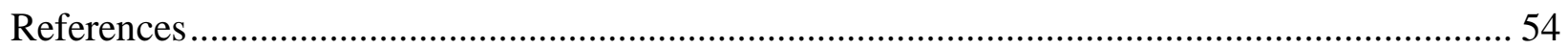




\section{List of Figures}

Figure 1: RD plots of loan spread on firms' reputation status .............................................. 40 


\section{List of Tables}

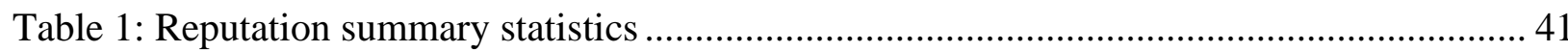

Table 2: Loan contract terms and firm characteristics summary statistics .................................. 42

Table 3: Firm reputation and the cost of bank debt ................................................................... 43

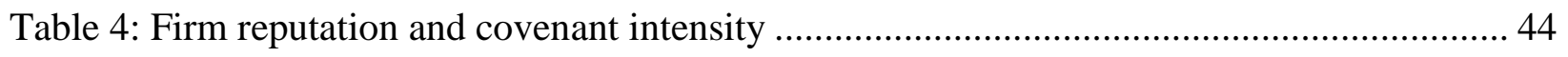

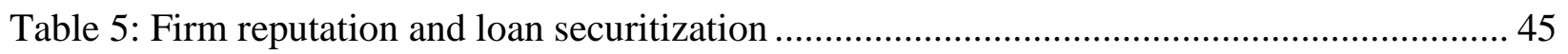

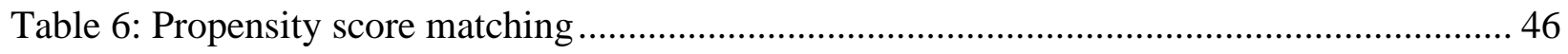

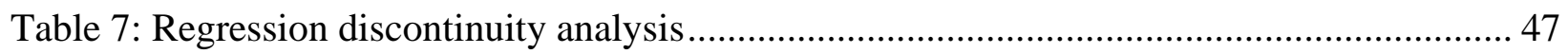

Table 8: Validity tests for regression discontinuity analysis ..................................................... 48

Table 9: Correlations of Halo Index Variables ............................................................................. 49

Table 10: Removing financial performance from MA scores and ranks..................................... 50

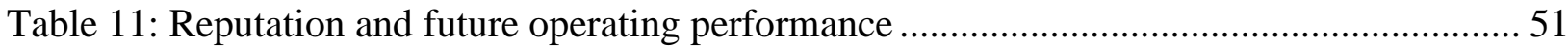

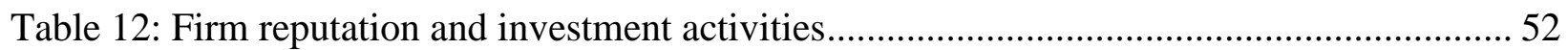




\title{
Firm reputation and the cost of bank debt
}

\begin{abstract}
This paper examines whether firm reputation impacts borrowing costs and thus investment. Using unique data from Fortune's Most Admired Companies surveys, I find that reputable borrowers enjoy lower borrowing costs and receive more favorable loan contract terms. My identification strategy is based on propensity score matching, a regression discontinuity design, and clean reputation measures removing the impact of prior financial performance. Further evidence suggests that banks reward reputable firms with better contract terms because this reputation proxy contains incremental information on borrower future performance and credit risk. Last, firms increase capital expenditures and $R \& D$ after receiving the Most Admired designation, consistent with reputable firms exploiting their lower cost of capital and with reputation having real effects on firms' investment policies.
\end{abstract}

JEL classification: G14, G21, G32, M3, L14, D82

Keywords: Firm Reputation; Cost of Bank Debt; Investment; Information Asymmetry 


\section{Introduction}

Bank debt has emerged as the predominant source of external financing for U.S. firms. While less than $20 \%$ of public firms have public debt, over $80 \%$ use private debt in the form of bank credit lines (Faulkender and Petersen, 2006; Sufi, 2009). Furthermore, the value of new issues of private debt - mainly bank debt — is more than double the value of new issues of public debt (Bradley and Roberts, 2015). Because bank debt is such a significant source of financing, it is important to understand the underlying factors affecting its cost as well as its real effects on firms' investment decisions.

Diamond $(1989 ; 1991)$ hypothesizes that access to capital markets and the cost of capital relate to firm reputation: Reputable firms should enjoy rents in the form of better access to capital markets at relatively lower costs. Indeed, reputable firms enjoy lower costs of equity and public debt (Cao et al., 2014; Anginer et al., 2011). Despite the increasing importance of bank debt in firms' capital structure, no prior research addresses the effect of reputation on the bank debt market. Bank debt is unique because - unlike equity market and public debt market participants — banks have privileged access to borrowers' inside information and exhibit superior information processing skills when evaluating borrowers' credit risk (Fama, 1985; Rajan, 1992; Cole, 1998; Denis and Mihov, 2003). Moreover, banks are more effective monitors than other lenders due to their closer relationships with borrowers (e.g., Fama, 1985; Diamond, 1984; 1991) and their ability to design and redesign contracts according to borrowers' performance (Bharath et al., 2008). Consequently, it is less clear whether banks incorporate external reputation signals into their evaluation of borrowers and reward reputable firms with better loan contract terms.

This paper examines the relation between reputation and bank debt. Specifically, I seek to answer three questions. First, is firm reputation priced in the bank debt markets? Second, does firm 
reputation signal useful information about borrower credit risk? Finally, what are the real effects of firm reputation on investment activities?

I measure firm reputation using survey scores from Fortune's America’s Most Admired Companies. Fortune's Most Admired list is the most widely used measure of firm reputation in both finance and accounting research. It covers a large sample of companies and allows for easy comparison across U.S. borrowers by quantifying firm reputation. Fortune's survey aggregates opinions from various industry experts and assesses both financial and non-financial aspects of reputation - from financial soundness to social responsibility to community and environmental issues. It is unlikely firms can influence this ranking because reputation building is costly and time-consuming and because the identity of survey respondents is private. For these reasons, Fortune's Most Admired list presents a suitable reputation proxy to test the relation between firm reputation and the cost of bank debt.

I begin by regressing the cost of bank debt on reputation, controlling for firm and loan characteristics and including firm and year fixed effects. I find that among all bank loans activated by the same borrowing firm, those activated after Fortune recognizing the borrowing firm as Most Admired are associated with a $13 \%$ lower interest rate. For the average loan in my sample, this reduction translates into a $\$ 4.7$ million savings in interest per loan facility. Results are robust to using survey scores and ranks instead of the binary Most Admired designation: A one standard deviation increase in Most Admired score (rank) leads to a 10\% (7\%) decrease in the cost of bank debt relative to its mean.

I next investigate how reputation impacts loan covenants and securitization. If banks perceive Most Admired firms as safer borrowers, they may impose less stringent non-price loan terms, i.e., less intense requirements for both covenants and collateral. Further results show that 
Most Admired firms are less likely to obtain loans with intense covenant structure and collateral requirements, consistent with reputable firms enjoying a lower borrowing cost and receiving better non-pricing contract terms.

Yet, it could be that Most Admired companies have better financial performance and lower credit risk, driving the relation between reputation and the cost of bank debt Univariate statistics indeed indicate that Most Admired borrowers differ from other borrowers along many observable dimensions: Most Admired firms tend to be larger, older, and more profitable than other firms. To alleviate endogeneity concerns, I conduct three additional tests. First, I propensity score match Most Admired "treatment" firms with control firms based on industry, year, and observable firm characteristics. The propensity score matching analysis continues to support a significant negative relation between firm reputation and the cost of bank debt.

Next, to eliminate the impact of potential correlated omitted factors, I conduct a regression discontinuity design (RDD). Using the industry median score as the cutoff, I cleanly identify counterfactual firms that would have earned the Most Admired designation if their scores had been only slightly different from the observed scores. Relative to firms just below the cutoff, firms just above the cutoff enjoy about $20 \%$ lower spreads associated with their newly originated loans.

Last, because Most Admired scores (ranks) are highly correlated with past financial performance, I remove the financial performance effect from Most Admired scores (ranks) following Brown and Perry (1994). Using the clean Most Admired scores and ranks, the main results still hold. Overall, my identification strategy based on propensity score matching, regression discontinuity design, and clean reputation measures supports firm reputation having a causal negative impact on the cost of bank debt. 
My findings suggest that banks indeed incorporate external reputation signals into their evaluation of borrowers. It is only optimal for banks to incorporate reputation into loan contracts if reputation provides incremental information about future borrower quality. Thus, I next test whether firm reputation predicts future firm performance or risk. Using Most Admired scores and ranks, I find higher reputation scores (ranks) predict higher future operating cash flows, lower stock return volatility, lower earnings per share (EPS) volatility, and lower probability of violating bank loan covenants. The evidence suggests that reputation status contains information about future borrower quality. This information contained in reputation status spurs banks to reward Most Admired firms with a lower borrowing cost.

To conclude, I examine whether the lower borrowing costs and better contract terms associated with firm reputation have real effects on investment activities. Because lower borrowing costs and better contract terms result in marginally unprofitable investments becoming profitable, I expect a positive relation between firm reputation and future investment spending. Indeed, Most Admired recognition produces a $0.13 \%$ increase in capital expenditure scaled by total assets and a $0.25 \%$ increase in $\mathrm{R} \& \mathrm{D}$ spending scaled by total assets, equivalent to a $4 \%$ and an $17 \%$ jump from their means. Similarly, a one standard deviation increase in Most Admired scores (ranks) produces a $0.29 \%(0.09 \%)$ increase in capital expenditures to total assets and a $0.22 \%(0.15 \%)$ increase in R\&D spending to total assets. Overall, the results are consistent with firms exploiting the lower cost of capital afforded by their good reputation to increase investments.

This paper contributes to several strands of literature. First, it relates to the large literature examining the determinants of the cost of bank debt. Whereas prior studies explain the differences in firms' borrowing costs using firm and industry characteristics such as firm size, leverage, and industry competition (e.g., Bhojraj and Sengupta, 2003; Klock et al., 2005; Chava et al., 2009; 
and Cremers et al., 2007), this paper identifies an increasingly important - yet unexplored determinant of firms' borrowing cost: reputation. Second, this study contributes to the banking literature by providing evidence that, although banks have advantages in producing private information about the borrowing firms (see, e.g., Leland and Pyle, 1977), broad reputation proxies such as Fortune's Most Admired list still provide valuable information about borrowers, which banks price into loan contracts. Finally, this paper adds to a growing body of research that investigates the economic consequences of firms' intangible assets, in this case firm reputation. While some studies suggest non-monetary benefits of firm reputation such as reduced litigation risks (e.g., Chen et al. 2009; Koh et al. 2014), many studies now have attempted to explore the quantifiable effects of intangible assets on company performance. To the best of my knowledge, there is no study providing direct evidence on how firm reputation affects investment activities. My evidence study fills this gap and provides evidence that borrowers take advantage of their good reputation status by increasing future spending on investments. These findings help to justify companies' efforts to dedicate resources towards intangible capital investments and thus have implications for managers weighing the costs and benefits of building or maintaining their firm's reputation.

The rest of the paper is organized as follows. Section 2 reviews the literature and develops the main hypotheses. Section 3 explains the data and presents summary statistics. Section 4 presents the analysis on the impact of firm reputation on both monetary and non-monetary loan contract terms. Section 5 provides the identification strategies that I use to establish causal relation between firm reputation and the cost of bank debt. Section 6 investigates the potential channels through which firm reputation affects firms' borrowing cost. Section 7 documents the real effects of firm reputation on firms' investment activities, and Section 8 summarizes the main findings. 


\section{Literature review and hypotheses development}

In this section, I first review the literature on reputation that motivates this study. Then, I develop the main hypotheses on how firm reputation impacts the cost of bank debt as well as the information channels through which reputation affects bank loans. Finally, I provide empirical predictions.

\subsection{Literature on bank loan contracting}

The banking literature considers one of the primary determinants of loan contracting to be the borrower's credit risk. To evaluate credit risk, banks analyze the borrower's financial characteristics. These characteristics include size, leverage, and profitability, which are associated with financial distress (e.g., Barclay and Smith, 1995; Stohs and Mauer, 1996; and Dennis et al., 2000); financial restatements and corporate misreporting (e.g., Graham, Li, and Qiu, 2008); and real asset illiquidity (e.g., Ortiz-Molina and Phillips, 2014). Banks factor these characteristics into the price and non-price terms of loan contracts.

A growing area of banking research studies how banks evaluate credit risk using the borrower's non-financial characteristics, such as corporate social responsibility investments (Goss and Roberts, 2011), supply chain stability (Cen, Dasgupta, Elkamhi, and Pungaliya, 2015), prior lending relationships (Bharath, Dahiya, Saunders, and Srinivasan, 2011), product market competition (Valta, 2012), political connections (Houston, Jiang, Lin, and Ma, 2014), and takeover risk and shareholder rights (Chava, Livdan, and Purnanandam, 2009). These studies suggest banks can assess risk by analyzing the borrower's non-financial profile. This study provides empirical

evidence that banks value firm reputation, a combination of financial and non-financial information, and incorporate it into loan contract terms. 


\subsection{Literature on firm reputation}

Firm reputation is the accumulated public recognition of firm quality. A growing research linking firm reputation to profitability (Roberts and Dowling, 2002), stock market returns, and financial reporting quality (Cao et al., 2012) suggests that firm reputation provides positive signals about future performance. Since reputation building is costly, Diamond $(1989 ; 1991)$ predicts that reputable firms will enjoy rents in the form of access to capital markets at relatively lower costs. Supporting this prediction, Cao et al. (2014) and Anginer et al. (2011) provide empirical evidence that firms recognized as Fortune's America's Most Admired Companies receive lower costs of equity and public debt, respectively. Less is known about how reputation impacts bank debt. Because bank debt has emerged as the predominant source of external financing, it is necessary to understand the underlying determinants of the cost of bank debt. Specifically, I study whether reputation reduces the cost of bank debt for large U.S. firms.

\subsection{Hypotheses development}

As discussed above, firms benefit from the public recognition of reputation in public debt and equity markets. However, whether banks value external reputation signals about borrowers is less clear. To investigate the relation between firm reputation and the cost of bank debt, I develop two hypotheses: the Informed Lender Hypothesis and the Information Asymmetry Hypothesis.

The Informed Lender Hypothesis posits that banks have access to private information about borrowers and superior information processing skills to evaluate borrowers' credit risk (Fama, 1985; Rajan, 1992; Cole, 1998; Denis and Mihov, 2003). If banks are already aware of the private information contained in firms' reputation status, they will not reward reputable borrowers with better loan contract terms. The Informed Lender Hypothesis thus predicts reputable borrowers do 
not receive better loan contract terms, i.e., interest rates, loan covenants, and securitization, than other borrowers.

Alternatively, the Information Asymmetry Hypothesis posits that even with access to inside information, banks cannot entirely overcome problems related to borrowers' information opaqueness (e.g., Bharath, J. Sunder, and S. Sunder 2008; Graham, Li, and Qiu 2008; Costello and Wittenberg-Moerman 2011; Kim et al. 2011a.). Broad reputation proxies such as Fortune's Most Admired Companies list, which aggregates opinions on financial and non-financial performance from various industry experts, can therefore provide banks with new information through a collective intelligence. For example, surveyed industry experts may be better suited to evaluate management quality, product quality, social responsibility, innovativeness, as well as the ability to attract talent. If so, banks gain valuable information from firms' reputation status, which they may incorporate into loan contract terms. The information asymmetry hypothesis predicts that reputable borrowers receive better contract terms in the form of lower interest rates, fewer covenants, and less collateral. In addition, because lower borrowing costs and better contract terms make marginally unprofitable investments, i.e., capital expenditure and R\&D, becoming profitable, this hypothesis also predicts that firms invest more in capital expenditure and R\&D after being recognized as Most Admired Companies.

Firm reputation contains information about future borrower quality. It is optimal for banks to incorporate external reputation signals into their evaluation of borrowers only if they are not aware of such information before they read borrowers' reputation status. To test if this is the case, I further develop two hypotheses: the Informed Signaling Hypothesis and the Noisy Signaling Hypothesis. The Informed Signaling Hypothesis posits that reputation contains information about 
borrowers' future credit risk; alternatively, the Noisy Signaling Hypothesis posits that reputation signals past firm quality but provides little information about future credit risk.

Information risk and default risk are two main components of credit risk. Specifically, information risk is the risk associated with the imperfect information that banks use to estimate borrowers' future operating cash flows (e.g., Bharath et al., 2008; Graham et al., 2008; Kim et al., 2011a), and default risk is the risk associated with borrowers not being able to meet their loan obligations, such as interest payments and principal repayment at maturity. Therefore, if reputation serves as a credible signal for borrowers' future credit risk, the Informed Signaling Hypothesis predicts that reputable firms have higher future cash flows, lower stock returns volatility, cash flow volatility, and debt violation probability. Alternatively, the Noisy Signaling Hypothesis predicts no relation between firm reputation and future cash flows, stock returns volatility, cash flow volatility, or debt violation probability.

\section{Sample selection and data sources}

\subsection{Firm reputation data}

Barnett, Jermier, and Lafferty (2006) define firm reputation as "observers' collective judgment of a corporation based on assessments of the financial, social, and environmental impacts attributed to the corporation over time." This definition assumes that firm reputation is based on long-term firm behavior and cannot be manipulated by firms' short-term actions. Below I argue that Fortune's Most Admired (MA) scores satisfy these assumptions.

I measure firm reputation using scores from Fortune's America's Most Admired Companies list, collected from print editions of Fortune magazine from 2001 to $2012 .{ }^{1}$ Fortune

\footnotetext{
${ }^{1}$ Fortune stopped publishing the Contenders, firms that have been rated but not recognized as Most Admired Companies, online or in the magazine since 2013.
} 
magazine creates the MA scores from a survey questionnaire. Since 1983, the Hay Group, on behalf of Fortune, has sent out surveys to senior executives, outside directors, and financial analysts from different industries in the U.S. and, on average, the response rate is around 50\%. The rated firms come from the Fortune 1000 list and for each industry the largest 10 firms based on revenue are identified for ranking. If fewer than 10 firms appear on the Fortune 1000 list for a given industry, then all firms in the industry are eligible for ranking. Each survey respondent rates the 10 largest firms from her own industry from 1 (poor) to 10 (excellent) on eight attributes: the ability to attract and retain talented people; the quality of management; the quality of products or services; innovativeness; long-term investment value; financial soundness; the wise use of corporate assets; and social responsibility to the community and to the environment.

For each attribute, the firm ranked first receives a score of 10 and the worst firm receives a score of 1. A firm's overall MA score is the equally weighted scores of the eight attributes. Although Fortune publishes both scores and ranks of the 10 largest firms in each industry, a firm's MA score must rank in the top half of its industry to be recognized as Most Admired Companies that year. The remaining firms that have been rated but not recognized as Most Admired Companies are referred as "Contender". Each year, the MA list features about 300 firms in more than 20 industries; Fortune magazine publishes scores and ranks the first quarter of the subsequent year. I create two indicator variables for reputation based on MA scores. Most Admired equals one if a firm's MA score ranks in the top half of its industry. Contender equals one if a firm's MA score ranks in the bottom half of its industry and thus not being recognized as Most Admired Companies.

Fortune's MA scores have several advantages over other possible reputation measures. First, consistent with the theoretical concept of firm reputation, the reported MA scores are based 
on various aspects of firm performance-from financial soundness to social responsibility to community and environmental issues. In addition, since building reputation is both costly and time-consuming, it is unlikely that firms can influence inclusion in this ranking. Last, given that the identity of survey respondents is not publicly available, it is unlikely that firms influence survey responses.

Table 1 reports the distribution of reputation proxies for my sample of 6,537 firm-year observations with MA scores. The average number of firms in the ranking each year from 2001 to 2012 is 545. The mean (median) MA score is 6.04 (6.07) and ranges from 3.04 to 8.83 , suggesting that the sample has considerable variation in the firm reputation measure. Among these ranked firms, 54\% are recognized as Most Admired and 46\% are listed as Contender firms.

\subsection{Bank loan data and descriptive statistics}

I collect bank loan data from Dealscan. To minimize any potential simultaneity biases, I measure firms' reputation in a given year and then assess the association between reputation and bank loan contracting terms one year later. Thus, the loan data are from 2002 through 2013. Since the reputation data are only available for U.S. firms for my sample period ${ }^{2}$, I limit the sample to loans issued by U.S. commercial banks and activated by U.S. firms. Dealscan provides loan data such as the interest charged, the fee structure of the loan, the loan covenant information, the size and maturity of the loan, as well as other dimensions of the loan. The basic unit of the analysis here is a loan, also referred to as a "facility" on the Dealscan database. Following prior literature, I calculate the cost of the bank loan as the natural logarithm of loan spread. Loan spread, shown as the Dealscan data item all-in-spread drawn (AIS drawn), is the amount the borrower pays in basis points over LIBOR for each dollar drawn. This measure adds to the borrowing spread any

\footnotetext{
2 Fortune has combined Most Admired list for Domestic and Foreign companies since 2009 and renamed the list
} "World's Most Admired Companies". 
relevant fees associated with the credit facility. Then, for each loan facility, I collect non-price terms including loan maturity, loan size, loan covenants, the number of lenders, whether it is secured by collateral, whether it is syndicated, loan types, loan purposes, and whether it uses performance pricing. All variables are defined in the Appendix.

I obtain firm-level accounting information from Compustat, stock price information from CRSP, and institutional ownership data from Thomson Financial. I first use a matching dataset provided by Michael Roberts to merge Dealscan and Compustat/CRSP data. ${ }^{3}$ Then, I manually match firm reputation data with the newly created loan dataset using firm name. A loan-year observation is included in the analysis if a firm has bank debt data (Dealscan), firm specific data from Compustat, institutional ownership data from Thomson Financial, and stock return data from CRSP. These limitations result in a full sample of 20,104 loan-year observations.

Panel A of Table 2 presents summary statistics of debt contract terms during 2002 to 2013, and univariate comparisons of these terms between Most Admired borrowers $(\mathrm{N}=2,183)$ and other borrowers $(\mathrm{N}=17,921)$. Given firms typically obtain multiple loan facilities every year and not all Most Admired firms have bank loan, the sample size changes from that in Table 1. The mean loan spread increases from 129.23 basis points over LIBOR for reputable U.S. borrowers to 228.49 basis points for non-reputable borrowers. The average loan size is bigger for reputable firms ( $\$ 1.123$ billion) than that of non-reputable firms ( $\$ 373$ million). The average loan maturity increases from 42 months for reputable firms to 48 months for non-reputable firms. In addition, I also find that loans activated by reputable borrowers are more likely to be syndicated ( 0.99 vs. 0.97), less likely to be collateralized ( 0.21 vs. 0.59$)$, and associated with higher annual fees (32.98 basis points vs. 17.28 basis points) but lower upfront fees (26.87 basis points vs. 49.57 basis points).

\footnotetext{
${ }^{3}$ I thank Michael Roberts for sharing the Dealscan-Compustat link data.
} 
Lastly, I compare the covenant intensity and the number of lenders between reputable and nonreputable firms and find that reputable borrowers have fewer financial covenants, less intense covenant requirements, and more lenders for each of their loans than non-reputable borrowers (0.82 vs. $1.47,0.95$ vs. 2.15 , and 9.91 vs. 5.44 ). Larger loans are associated with more lenders and reputable borrowers' loans are on average almost four times as large non-reputable borrowers' loans. All the above differences between reputable and non-reputable U.S. borrowers are statistically significant at $1 \%$ level. Overall, this evidence suggests that both price and non-price loan contract terms vary with firm reputation.

Panel B of Table 2 summarizes firm characteristic for Most Admired borrowers $(\mathrm{N}=1,326)$ and other borrowers $(\mathrm{N}=10,951)$ and shows univariate comparisons across the two groups. Most Admired borrowers tend to be larger, older, and more profitable, which may reflect the coverage in Fortune's MA list being limited to the largest firms measured by sales. Compared to other borrowers, Most Admired borrowers have greater growth opportunities, fewer tangible assets, and lower sales growth rates. In addition, the capital structure of Most Admired firms also differs from that of other firms: Most Admired firms hold less cash, suggesting that reputable borrowers may have greater financial flexibility than less reputable firms. Most Admired firms' average Z-score is higher and their cash flow volatility is lower, suggesting that Most Admired firms have more stable financial conditions and face lower bankruptcy risk. Lastly, Most Admired firms are more likely to obtain Standard \& Poor's credit rating and more likely to be rated investment grade by Standard \& Poor's ( 0.91 vs. 0.46 and 0.81 vs. 0.21$)$. 


\section{Multivariate analysis}

\subsection{Effect of reputation on the cost of bank debt}

Table 2 shows the many differences in firm characteristics between reputable and nonreputable firms. To control for differences in borrower characteristics that may affect the cost of bank debt as well as other debt contract terms, I estimate multivariate regressions of the cost of bank debt on firm reputation, controlling for other loan terms and firm characteristics. The main empirical model is as follows:

Cost of bank debt $t_{i, s, j, t}$

$$
\begin{aligned}
& =\alpha_{1}+\alpha_{2} \text { Reputation }_{i, j, t-1}+\alpha_{3} \text { Firm }_{\text {characteristics }} \text { i }_{j, t-1} \\
& +\alpha_{4} \text { Loan characteristics }_{s, t}+\delta_{t}+\gamma_{i}+\epsilon_{i, j, t}
\end{aligned}
$$

Each observation represents a single loan, where Cost of bank debt is the natural logarithm of the loan spread for the loan that is initiated after Fortune published the America's Most Admired Companies list. I measure firm reputation using Fortune's MA list one year before the loan is initiated. If reputable firms enjoy rents in the form of lower cost of bank debt (Diamond 1989;1991), I expect the coefficient on $\alpha_{2}$ to be negative. All standard errors are clustered at the firm level.

I add important determinants of the cost of bank debt documented in prior literature (Bharath et al., 2007; Graham et al., 2008). Firm-level controls include size, age, growth opportunities, leverage, asset tangibility, profitability, sales growth, institutional ownership, cash flow volatility, Altman's Z-score, and credit rating indicator. Loan-level controls are maturity, size, syndicated loan indicator, performance pricing clause indicator, prior lending relationship, as well as loan type and purpose indicators. I compute firm characteristics using financial and accounting information from the closest prior fiscal year end to the loan initiation year. 
In addition, firm and year fixed effects control for potential endogeneity and unobservable heterogeneity that could cause a spurious relation between firm reputation and cost of bank debt. Therefore, any omitted variable in the model would have to be an idiosyncratic, time-invariant firm or loan characteristic unrelated to the firm and loan controls described above. I am unaware of such a variable.

Table 3 reports the results. The dependent variable is Cost of bank debt, the natural logarithm of loan spread. The coefficient on Most Admired in Model (1) is -0.144 with a t-statistic of -5.216, suggesting that being recognized as Most Admired Companies reduces a firm's borrowing cost by $13 \%$ in the subsequent year. For the median loan in my sample, this translates into a reduction of loan spread by about 26 basis points. ${ }^{4}$ Given the loan size and the time to maturity in the sample, on average, are $\$ 454.62$ million and around 48 months, respectively, the reduction will translate into $\$ 4.7$ million interest payment per loan facility. Because rated firms are the largest firms from each industry, I then study the reputation effects among these industry leaders by focusing only on firms with MA scores. Models (2) to (4) report the results. The coefficient on Most Admired in Model (2) is -0.144 with a t-statistic of -3.648 , suggesting that being recognized as Most Admired indeed reduces firms' borrowing cost by $13 \%$ and that this reputation effect holds among industry leaders. The negative coefficient on Score in Model (3) suggests that compared to loans activated in a firm's low-score years, loans activated during the firm's high-score years are associated with lower costs of bank debt. A one standard deviation increase in the MA score leads to a $10 \%$ decrease in the cost of bank debt. Similarly, the negative coefficient on Rank in Model (4) suggests that a one standard deviation increase in the MA ranking

\footnotetext{
${ }^{4}$ The median loan spread is 200 basis points.
} 
leads to an 7\% decrease in the cost of bank debt. Taken together, results from Table 3 consistently show that reputable firms incur lower borrowing costs.

The coefficient estimates of control variables take on expected signs. Mature, profitable firms, and firms with lower default risk, measured by Altman's Z-score and leverage, receive lower cost of bank debt. The coefficients on Lending relationship is negative, suggesting that it is easier for borrowers to obtain credit at a lower rate based on established lending relationship. The coefficient on Loan Size is negative and statistically significant, consistent with economies of scale (that borrowers with larger loans receive favorable interest rates). Last, the borrowing cost is significantly lower for loans with a performance-pricing clause.

\subsection{Effect of reputation on other loan contract terms}

Banks also mitigate risks by adjusting adjust non-price loan contract terms (Strahan, 1999). Moreover, compared to the dispersed public bondholders, banks have superior information from the borrower, face lower renegotiation costs, and thus have greater incentives to use "detailed and tailor-made contracts" (Bharath, Sunder, and Sunder, 2008). For example, Graham, Li, and Qiu (2008) and Hasan, Hoi, Wu, and Zhang (2014) find that banks impose more stringent collateral and covenant requirements when lending to firms with greater risks.

Accordingly, if banks perceive firms' reputation concerns as constraining moral hazards in debt contracting, or banks trust good-reputation firms more, one would expect that banks impose less stringent non-price loan terms, i.e., fewer collateral and covenants requirements, when lending to good-reputation firms.

\subsubsection{Covenant intensity}

To estimate the impact of firm reputation on the covenant intensity of a loan, I follow Bradley and Roberts (2015) and calculate the covenant intensity index. The covenant intensity 
index is defined as the sum of six covenant indicators (collateral, dividend restriction, indicator for a loan facility requiring more than two financial covenants, asset sales sweep, equity issuance sweep, and debt issuance sweep). The index ranges from 0 through 6 . Then I regress the covenant intensity index on firm reputation and other control variables that could correlate with the covenant intensity in an OLS model in Table 4. The estimated coefficient on Most Admired in Model (1) indicates that, even when lending to the same borrower, lenders base covenant requirements on reputation: A firm is less likely to obtain loans with intense covenant structures if it has been recognized as Most Admired the previous year. Then, I test whether this reputation effect still holds among firms with MA scores. The coefficient estimates on Most Admired, Score, and Rank are all significantly negative, consistent with firms receiving better reputation scores and ranks being considered safer borrowers and thus receiving fewer loan restrictions.

\subsubsection{Loan securitization}

I further study the impact of firm reputation on the likelihood of a loan being secured by collateral in Table 5. The dependent variable is Loan securitization, which equals one if the loan is secured by collateral and zero otherwise. The coefficients on Most Admired in Models (1) and (2) both suggest that firms are less likely to provide collateral to secure their loans after they are recognized as Most Admired. The effects of control variables on the likelihood of the loan being collateralized are also intuitive: Firms with higher cash flow volatility have higher default risk and thus are associated with a higher probability of a loan being secured. The estimated coefficients on both Score and Rank imply that the likelihood of a loan being secured is lower when borrowers received higher MA scores and ranks; a one standard deviation increase in a firm's MA scores (ranks) reduce the likelihood of having a secured loan by $3 \%(3 \%)$. 


\section{Identification strategy}

The evidence so far suggests reputable borrowers benefit from their good reputation, enjoying a lower cost of bank debt and receiving better loan contract terms from their lenders. One potential concern is the endogenous nature of the MA scores. Common factors could lead to both a good reputation and lower borrowing costs for Most Admired firms. Thus, I conduct three different analyses to address the potential endogeneity problem and establish causality between firm reputation and the cost of bank debt.

\subsection{Propensity score matching}

Univariate statistics indicate that America's Most Admired firms differ from other firms along many observable dimensions. To avoid estimating biased treatment effects, I create a propensity score matched sample where firms have similar covariates but differ only on the reputation status. In my context, I consider "treatment" to be firms recognized as Fortune's Most Admired Companies. I start by matching each treatment firm to the closest control firms from the pool of Contender firms, first exactly on year and three-digit SIC and then on the closest propensity score arising from a logistic regression on firm size, firm age, market-to-book, tangibility, z-score, profitability, cash, sales growth, institutional ownership, and leverage. Control firms are drawn with replacement. The treatment and matched control groups do not differ in any of the matching characteristics or propensity scores (Panel A Table 6).

Panel B of Table 6 reports the average treatment effect on the treated, i.e., the difference in the cost of bank loans or other debt contract terms between Most Admired firms and similar untreated Contender firms. Specifically, Most Admired borrowers receive 7\% lower borrowing cost, are $35 \%$ less likely to obtain loans with intense covenant requirements, and are 6\% less likely to provide collateral to secure their loans than otherwise similar Contender firms. Overall, the 
results are consistent with firms benefiting from their good reputation with lower bank debt costs and better contract terms.

\subsection{Regression discontinuity analysis}

Another potential endogeneity concern is that an omitted variable may correlate with both firm reputation and the cost of bank debt. To further strengthen identification, I conduct a regression discontinuity (RD) analysis to exploit locally exogenous changes around the threshold. The advantage of a regression discontinuity (RD) design is that it cleanly identifies counterfactual firms that could have entered the MA list if their MA scores had been only slightly different from those observed, and thus mitigates endogeneity concerns.

According to the methodology provided by Fortune magazine, a firm's MA score must rank in the top half of its industry to be recognized as Fortune's America's Most Admired Companies. The remaining firms that have been rated but not recognized as Most Admired Companies are referred as "Contenders". Therefore, I choose the industry median score as the cutoff that separates Most Admired firms from Contender firms. ${ }^{5}$ I assign positive (negative) sequence numbers to firms whose scores are above (below) their industry median and set the cutoff as zero.

Figure 1 presents the relation between firms' cost of bank debt and rankings relative to the cutoff of industry median. Firms not recognized as Most Admired are to the left of the threshold, and firms recognized as Most Admired are to the right. Firms ranked zero receive MA scores just above the industry median. Each dot represents the average loan spread within each bin, and the range around each dot represents the $95 \%$ confidence interval. The figure shows that within the

\footnotetext{
${ }^{5}$ Prior studies that also use America's Most Admired Companies list to measure firm reputation usually choose a rank of 100 as the cutoff, arguing that firms that are outside the rank of 100 do not advertise their MA ranks (Focke, Maug, and Niessen-Ruenzi, 2017). However, the number of firms being ranked may vary across different industries, resulting more/fewer than ten firms shown on the MA list for a given industry.
} 
proximity of the zero-cutoff point, the cost of debt decreases significantly once a firm becomes Most Admired. This finding suggests a causal impact of firm reputation on the loan spread.

Next, I implement the polynomial regression for the RD analysis using the following equation:

$$
\begin{aligned}
& \text { Cost of bank debt } t_{i, s, j, t} \\
& =\alpha_{1}+\alpha_{2} \text { Most Admired }_{i, j, t-1}+\alpha_{3}(\text { Relative Rank }-0)_{i, j, t-1} \\
& +\alpha_{4} \text { Most Admired }_{i, j, t-1} *(\text { Relative Rank }-0)_{i, j, t-1}+\alpha_{5} \text { Controls }_{s, t}+\delta_{t} \\
& +\gamma_{j}+\epsilon_{i, j, t}
\end{aligned}
$$

The dependent variable is the cost of bank debt, the natural logarithm of the loan spread for the loan activated one year after the MA list is published. The variable Most Admired equals one if a firm is recognized as Fortune's Most Admired Companies. Relative rank is the withinindustry rank relative to the industry median rank of zero. For example, Most Admired firms with the lowest score within the industry have Relative rank of zero and other firms that receive the highest scores will have Relative rank of negative one. In addition, I include controls for firm characteristics and loan characteristics. Note that I include industry and year fixed effects in Models (1) to (4) to catch the MA recognition effect for any firms that are around the cutoff, and firm and year fixed effects in Models (5) and (6). The inclusion of firm fixed effects means that my identification stems only from firms that switch MA status over the course of the sample period, rather than just any firm that was ever "close" to the threshold. Standard errors are clustered at the firm level.

Table 7 presents the RDD estimation results. Model (1) includes Most Admired and Relative rank without the interaction term or control variables. The coefficient on Most Admired suggests a $22 \%$ fall in the cost of bank debt for loans activated by reputable borrowers whose MA 
scores just pass the industry median. The estimated coefficient on Relative rank is also negative and statistically significant, which is consistent with the view that firms with better reputation receive lower cost of bank debt. Model (2) includes the interaction of Most Admired and Relative rank to gauge the difference in the reputation effect between Most Admired borrowers and Contender borrowers. The coefficient on the interaction term is positive and statistically significant, suggesting that Relative rank matters less once a firm is recognized as Most Admired Companies. Models (3) and (4) include control variables known to affect firms' cost of bank debt. Both coefficients on Most Admired are negative and statistically significant. In Models (5) and (6), I replace industry fixed effects with firm fixed effects. This marginally increases the standard errors but does not meaningfully affect inferences. The coefficients on Most Admired suggest a 17-23\% fall in the cost of bank debt for loans activated after a firm being recognized as Most Admired Companies. Overall, the results provided in Table 7 are consistent with a causal impact of firm reputation on the cost of bank debt.

The regression discontinuity analysis relies on the "random assignment" assumption, which requires being just above or below the cutoff to be random. All factors other than the treatment variable should thus vary continuously at the cutoff. To verify the validity of this assumption, I perform two sets of tests to examine the distribution of ex ante firm characteristics around the Most Admired resignation cutoff. First, I run a local linear model regressing each firm characteristic on Most Admired, Relative Rank, Most Admired*Relative Rank, and control variables. If the distribution of ex ante firm characteristics is smooth around the cutoff, none of the coefficient estimates on Most Admired should be statistically significant. Consistent with this expectation, Table 8 begins by showing that, for each characteristic, Most Admired is not statistically significant. Second, I compare the average values of each firm characteristic across 
the two closest firms around the cutoff. The remainder of Table 8 reports summary statistics as well as difference in means tests between the two closet firms around the cutoff (one on each side). The univariate tests again confirm the differences are insignificant between the Most Admired and other firms around the cutoff, suggesting that the predetermined characteristics of firms whose scores are just above and just below the industry median should have no systematic differences. The combined evidence is consistent with the random assignment assumption and suggests that the estimates from the RD analysis should be attributed to the causal effect of firm reputation.

\subsection{Removing financial performance from MA scores and ranks}

Another concern with using Fortune's MA scores to measure firm reputation is that they are heavily influenced by prior financial performance (Brown and Perry, 1994) and may simply proxy for financial performance or risk. Following Brown and Perry (1994), I create the financial halo index using five financial and operating variables: operating return on assets (contemporaneous and lagged one period), industry-adjusted market to book, sales growth, sales, and leverage. ${ }^{6}$ Table 9 presents the correlation matrix of the financial halo index variables and firm reputation measures. Firm reputation status strongly correlates with the financial halo index variables: Reputation is positively correlated with profitability, sales growth, market-to-book ratio, and sales, but negatively correlated with leverage ratio. To remove this financial halo effect, I follow Brown and Perry (1994) and estimate a model of MA scores (ranks) as a function of a halo index. The residual from the estimation model represents the intangible assets related to reputation effects that cannot be obtained by analyzing financial statements and market data. I employ the residual from this model as the clean MA scores (ranks) and re-estimate the main model.

\footnotetext{
${ }^{6}$ I only include one lag of profitability as further lags are insignificant. I include no lags of growth, sales, market-tobook, and leverage because these are not statistically significant. Using further lags or no lags, as well as using just a subset of these variables, does not affect my findings.
} 
Table 10 presents the results. In Models (1) and (2), the dependent variable is Cost of bank debt, measured as the natural logarithm of the loan spread. Both estimated coefficients on Clean MA score and Clean MA rank are negative and statistically significant, confirming that firms with higher MA scores and ranks receive a lower borrowing cost. Models (3) and (4) test whether firms with better reputations are less likely to obtain loans with intense covenant structure. The estimated coefficients on Clean MA score is -0.112 , significant at the $10 \%$ level. This evidence confirms the main finding that reputable borrowers are considered safer borrowers and thus receive loans with fewer restrictions than less reputable firms. In Models (5) and (6), the dependent variable is Loan securitization, which equals one if the loan is secured by collateral and zero otherwise. The estimated coefficients on Clean MA score and Clean MA rank are negative and statistically significant, implying that reputable borrowers are less likely to be required to provide collateral against their loans than less-reputable borrowers are. Overall, after removing the financial performance halo from Fortune's MA scores (ranks), I still find consistent evidence that reputable firms benefit from their good reputation, incurring lower borrowing costs and receiving better loan contract terms from lenders.

\section{Channels through which reputation affects the cost of bank debt}

In this section, I examine the channels through which reputation benefits borrowing firms. On one hand, reputation can signal factors associated with firm quality, such as a high quality management team, innovation capability, talented employees, etc., which are important but difficult for potential lenders to measure. If reputation provides a positive, credible signal to lenders about borrower credit risk, I expect a positive relation between firm reputation and future performance and a negative relation between firm reputation and future credit risk. On the other 
hand, banks may perceive good-reputation firms as more trustworthy simply because reputation building is complex (Reed and DeFillippi, 1990), time-consuming (Dierickx and Cool, 1989), and difficult to imitate (Barney, 1991). Additionally, banks may already have the information contained in firms' reputation since they have access to private information about the borrowing firms and a superior information processing skills to evaluate borrowers' credit risk (Fama, 1985; Rajan, 1992; Cole, 1998; Denis and Mihov, 2003). Therefore, firms' reputation status may not relate to with firm future performance and/or credit risk.

First, I regress firms' future cash flows from operations, scaled by total assets, on my reputation measures. Table 11 presents the results. Estimation results in Model (1) and (2) suggest that a one standard deviation increase in MA score (rank) produces a $0.6 \%(0.6 \%)$ future operating cash flow, equivalent to a $5 \%(5 \%)$ increase from the mean. ${ }^{7}$

Then, I test whether reputable firms have lower idiosyncratic risk, measured by the standard deviation of a borrower's daily stock return over the two fiscal years after a firm receives the MA score/rank (Campbell and Taksler, 2003). Estimation results in Models (3) and (4) show that MA score and rank are significantly negatively related to future stock return volatility, suggesting that reputable borrowers having lower idiosyncratic risk. In terms of economic magnitude, a one standard deviation increase in MA score (rank) is associated with a $0.6 \%(0.3 \%)$ lower return volatility, equivalent to $6 \%(3 \%)$ lower than the mean. ${ }^{8}$

Next, I test whether reputation predicts future earnings per share (EPS) volatility. EPS volatility, measured as the standard deviation of annually EPS over the three years after Fortune's MA list is published, proxies for earnings risk and is expected to be an important factor for lenders when evaluating loans. If reputation predicts earnings risk, I expect a significantly negative relation

7 The mean ratio of operating cash flow to total assets is $12 \%$.

8 The mean ratio of stock return volatility is $10 \%$. 
between firm reputation and future cash flow volatility. The coefficients on reputation measures in Models (5) and (6) are significantly negative, suggesting that the incremental information that banks obtain from reading borrower's reputation status help them to predict borrower's future earnings risk.

Finally, I examine whether reputable firms have a lower probability of debt covenant violation in a given issuance year (Demerjian and Owens, 2016). The dependent variable, Probability of Covenant Violation, is the aggregate probability of covenant violation across all covenants included on a given loan package. If a borrower's reputation status predicts loan covenant violation, I expect a negative relation between firm reputation and Probability of Covenant Violation. Models (7) and (8) report the results. The estimated coefficients on MA score and rank are both negative and statistically significant, suggesting that firms with higher MA scores and ranks are less likely to violate their loan covenants.

Overall, firms' reputation status has predictive power on future operating performance, lower idiosyncratic risk, future earnings risk, and lower loan violation probability. The evidence is consistent with reputation status containing incremental information about future firm quality, and lenders thus rewarding reputable borrowers with lower interest rates and better loan contract terms.

\section{The real effects of firm reputation}

Credit constraints have real effects on firms' day-to-day operations. For example, Chava and Roberts (2008) identify debt covenants as a channel through which financing frictions may affect firms' investment activities; they find firms reduce capital expenditures after a covenant violation. Focusing on the financial crisis, Campello et al. (2010) show that constrained firms 
suboptimally cut investments while unconstrained firms cut investments significantly less. I have shown that firms with good reputations enjoy lower borrowing costs and better contract terms. If the "America's Most Admired Companies" label helps firms obtain lower borrowing costs and better contract terms, I expect reputation to translate into more investment the next year. Therefore, in this section, I test the real effects of reputation on investment activities.

Following Chava and Roberts (2008), I first test how a firm's reputation affects its capital expenditures. I regress capital expenditure, scaled by total assets, on reputation measures. I control for firm characteristics that may influence investment decisions, including firm size, age, marketto-book, asset tangibility, Z-score, cash, sales growth, and leverage. All controls are scaled by total assets. I also include firm and year fixed effects to control for time-invariant heterogeneity across firm and time, and I cluster standard errors at the firm level. Panel A Table 12 presents the results. The Most Admired coefficient estimate in Model (1) is significantly positive, suggesting that firms tend to increase capital expenditures the year they receive Fortune's America's Most Admired Companies recognition. Using alternative reputation proxies, I find similar-if not strongerresults for this positive relation, confirming that the year a firm is assigned a higher rank(score), the greater the capital expenditures it spends. Being recognized as Fortune's Most Admired Companies in a given year is associated with a $0.13 \%$ increase in capital expenditure in the same year, equivalent to a $3 \%$ jump from the mean. ${ }^{9}$ A one standard deviation increase in MA scores (ranks) produces a $0.29 \%(0.09 \%)$ increase of capital expenditure in total assets, equivalent to a $8 \%(2 \%)$ increase from the mean.

I next examine the relation between firm reputation and research and development expenses (R\&D). The returns to $R \& D$ projects are skewed and highly uncertain; R\&D projects

\footnotetext{
${ }^{9}$ The mean ratio of capital expenditure to total assets is $3.8 \%$.
} 
have a low probability of financial success (Mansfield et al., 1977; Harhoff et al. 1999). With limited access to debt, firms may find $R \& D$ investments suboptimal. If reputation allows firms to obtain bank loans with lower costs and better contract terms, one may expect that after being recognized as Most Admired companies, firms will increase their capital spending in R\&D projects. Consistent with my expectation, the evidence suggests a positive relation between firms' MA scores (ranks) and R\&D expenses. Compared with the R\&D spending in years that a firm is not recognized as Most Admired Companies, R\&D spending in years with Most Admired recognition increases $0.25 \%$, which is equivalent to a $17 \%$ jump from its mean. ${ }^{10}$

Thus far, the results are consistent with the prediction that good-reputation firms receiving lower borrowing costs tend to take advantage of their reputation to invest more on both capital expenditures and R\&D. However, reputable firms may also receive lower financing costs in othe markets (Cao et al., 2014; Anginer et al., 2011). To further show that reputable firms indeed exploit their reputation benefits in the bank debt and invest more, I examine the real effect of reputation on firms' investment activities within subsample of firms with and without bank debt. If reputable firms adjust their future investment policy because of the lower borrowing costs, I expect a stronger reputation effect within the subsample of firms that actually obtain bank loans. Models (4) through (6) in Panel A and Panel B show that within firms that obtain at least one bank loan in the previous year, reputable firms invest more in both capital expenditure and R\&D. However, in Model (7) through (9), I do not find significant reputation effects on firms' investment decisions within the subsample of firms that hold no bank loans. These subsample analyses ensure that one reason reputable firms invest more is that they tend to exploit the reputation benefits in the bank debt market.

\footnotetext{
${ }^{10}$ The mean ratio of $R \& D$ expenses to total assets is $1.5 \%$.
} 


\section{Conclusion}

Firm reputation has attracted attention from both investors and academia during the past several decades, motivating research on whether establishing a good reputation creates value for shareholders, especially through financing activities. In a similar vein, Anginer et al. (2011) show that reputable firms receive lower financing costs when they issue equity, and Cao et al. (2015) find that establishing a good reputation can lower the cost of public bonds. Their focus on public equity and public debt leaves an open question on whether similar results hold for bank debt, which has become more important in corporate capital structures over recent decades.

This study adds to the growing body of literature on the effects of firm reputation, the determinants of the cost of bank debt, and the determinants of firms' investment activities. I provide empirical evidence that reputable firms enjoy lower borrowing costs and receive better debt contract terms: Reputable firms' loans are larger, mature sooner, are associated with lower fees, have fewer covenants, and are less likely to be secured. I further show that reputation is positively associated with future operating cash flows. This evidence suggests that firms' reputation contains important, private information about future firm quality and that lenders reward reputable borrowers with a lower interest rate. Last, I document the real effects of reputation on investment activities: Reputable firms take advantage of their lower cost of capital to invest more in both physical assets (capital expenditures) and intangible assets (R\&D). 


\section{Appendix: Variable Definitions}

\section{Firm Characteristics:}

Firm size: The natural logarithm of the book value of total assets. Larger firm, usually considered having less information asymmetry and suffering less from adverse selection problems, are expected to receive lower borrowing costs.

Firm age: The natural logarithm of a firm's age. Firm age is calculated based on the firm's founding date from Jay Ritter's website. If the founding date is missing, I replace the founding date using the earliest appearance date of a firm on Compustat. Similar to larger firms, older firms are usually considered having less information asymmetry and suffering less from adverse selection problems, and thus receive lower borrowing costs.

Market-to-book: Total assets less book value of equity plus market value of equity scaled by total assets. On one hand, firms with higher market-to-book ratios are usually considered with higher growth opportunities and thus receive lower borrowing costs. On the other hand, banks may consider firms with higher market-to-book ratios as borrowers with higher uncertainties and thus require higher interest rates.

Leverage: The ratio of the book value of total debt to the market value of equity plus the book value of total debt. Highly levered firms are usually considered having higher default risk and are thus expected to have higher borrowing costs.

Profitability: Operating income before depreciation (EBITDA) scaled by total assets. Profitable firms are more capable of making interest payments on time and principal payments on maturity date. Therefore, I expect profitable firms receive lower borrowing costs.

Cash: Cash and cash equivalent holdings scaled by total assets. Firms with more cash are considered having lower default risk and thus receive lower borrowing costs.

Capital expenditure: Capital expenditure scaled by total assets.

R\&D expenses: Research and development expense scaled by total assets.

Tangibility: Net property, plant and equipment scaled by total assets. Firms with more tangible assets are considered having lower default risk and thus receive lower borrowing costs.

Sales: Sales in current year.

Sales growth: Sales in current year minus sales last year over sales last year.

Institutional ownership: The fraction of shares outstanding owned by institutions, collected from the $13-\mathrm{f}$ filings by Thomson Reuters. Prior literature documents a negative relation between the presence of institutional ownership and the cost of capital because of the monitoring they provide.

Z-score: Modified Altman's (1968) Z-score 1/4 (1.2 working capital+1.4 retained earnings+3.3 EBIT+0.999sales)/total assets. I use a modified Z-score, which does not include the ratio of market value of equity to book value of total debt, because a similar term, market-to-book, enters the regressions as a separate variable. A higher Z-score indicates lower default risks. Therefore, I expect firms with higher Z-score receive lower borrowing costs.

Cash flow: Cash flow is measured as annual sales minus cost of goods sold, general and administrative expense, and changes in working capital, scaled by total assets. Similar to Cash, firms with higher cash flow levels are considered having lower default risk and thus receive lower borrowing costs. 
Cash flow volatility: Standard deviation of quarterly cash flows from operations over the 36 fiscal quarters after a firm being recognized by Fortune's MA list scaled by total assets. Risker firms have higher borrowing costs because their cash flow are more volatile.

Credit rating: Dummy variable equal to one if the firm has been rated by Standard \& Poor's in current year and zero otherwise. The presence of a credit rating is usually considered as proxy of the degree of information asymmetry. I expect firms with a credit rating receive lower borrowing costs.

Investment grade: Dummy variable equal to one if the firm has been rated as investment grade by Standard \& Poor's in current year and zero otherwise. The presence of an investment grade credit rating is usually considered as proxy of the degree of information asymmetry and thus negatively related to the cost of bank debt.

Earnings per share (EPS) volatility: Standard deviation of annual earnings per share (EPS) from operations over the three years after a firm being recognized by Fortune's MA list scaled by total assets.

\section{Reputation Measures:}

Most Admired: Dummy variable equal to one if the firm has been recognized as "America's Most Admired Companies" in current year and zero otherwise.

Contender: Dummy variable equal to one if the firm has been rated but NOT recognized as "America's Most Admired Companies" in current year and zero otherwise.

Score: The overall mean of a firm's scores on eight reputation attributes in current year.

Rank: Firm's score-based rank within its industry in current year multiply by negative one.

Clean MA score: The residual from the estimation model that regresses raw MA score on five financial and operating variables: operating return on assets (contemporaneous and lagged one period), industry-adjusted market to book, sales growth, sales, and leverage.

Clean MA rank: The residual from the estimation model that regresses raw MA rank on five financial and operating variables: operating return on assets (contemporaneous and lagged one period), industry-adjusted market to book, sales growth, sales, and leverage.

\section{Loan Characteristics:}

Loan spread: All-in spread drawn, defined as the amount the borrower pays in basis points over LIBOR or LIBOR equivalent for each dollar drawn down. (For loans not based on LIBOR, LPC converts the spread into LIBOR terms by adding or subtracting a differential which is adjusted periodically.) This measure adds the borrowing spread of the loan over LIBOR with any annual fee paid to the bank group.

Cost of bank debt: The natural logarithm of loan spread.

Loan size: The natural logarithm of the loan facility amount. Loan amount is measured in millions of dollars.

Maturity: The natural logarithm of the loan maturity. Maturity is measured in months.

Security: Dummy variable equal to one if the loan facility is secured by collateral and zero otherwise.

Number of lenders: Total number of lenders in a single loan.

Performance pricing dummy: Dummy variable equal to one if the loan facility uses performance pricing.

Number of financial covenants: Total number of financial covenants in a single loan. 
Covenant intensity: The sum of six covenant indicators (collateral, dividend restriction, more than two financial covenants, asset sales sweep, equity issuance sweep, and debt issuance sweep).

Loan type: Indicator variables for types of loans including term loan, revolving loan less than one year, revolving loan greater than one year, 364-day facility, and bridge loan separately

Loan purpose: Indicator variables for purposes of loans such as corporate purposes, working capital, LBO, debt repayment, takeover, leveraged buyouts, et cetera.

Syndicate: An indicator variable, which is one if a loan is syndicated, and zero otherwise.

Lending relationship: The proportion of the total amount borrowed in the previous five years where the current lead arranger acted as a lead arranger. It is easier for firms to obtain credit at a lower cost based on an established lending relationship.

Probability of Covenant Violation: The aggregate probability of covenant violation across all covenants included on a given loan package. 


\section{Figure 1: RD plots of loan spread on firms' reputation status}

This plot presents the relation between the cost of bank debt and firms' reputation status measured by rank relative to the industry median score. Firms whose MA scores are greater than or equal to the industry median score, i.e., America's Most Admired Companies, receive a non-negative sequence number starting with zero, and these MA firms are shown on the right of the figure. Firms whose MA scores are less than the industry median score receive a negative sequence number stating with negative one, and these nonMA firms are shown on the left of the figure. The size of the bin in all plots is one. Each dot represents the average of the natural logarithm of the loan spread for loans activated after MA list publication, and the range of each dot represents the $95 \%$ confidence interval. The solid lines represent the fitted values of a second-degree polynomial of Relative Rank to Industry Median on the interval of -5 to 4.

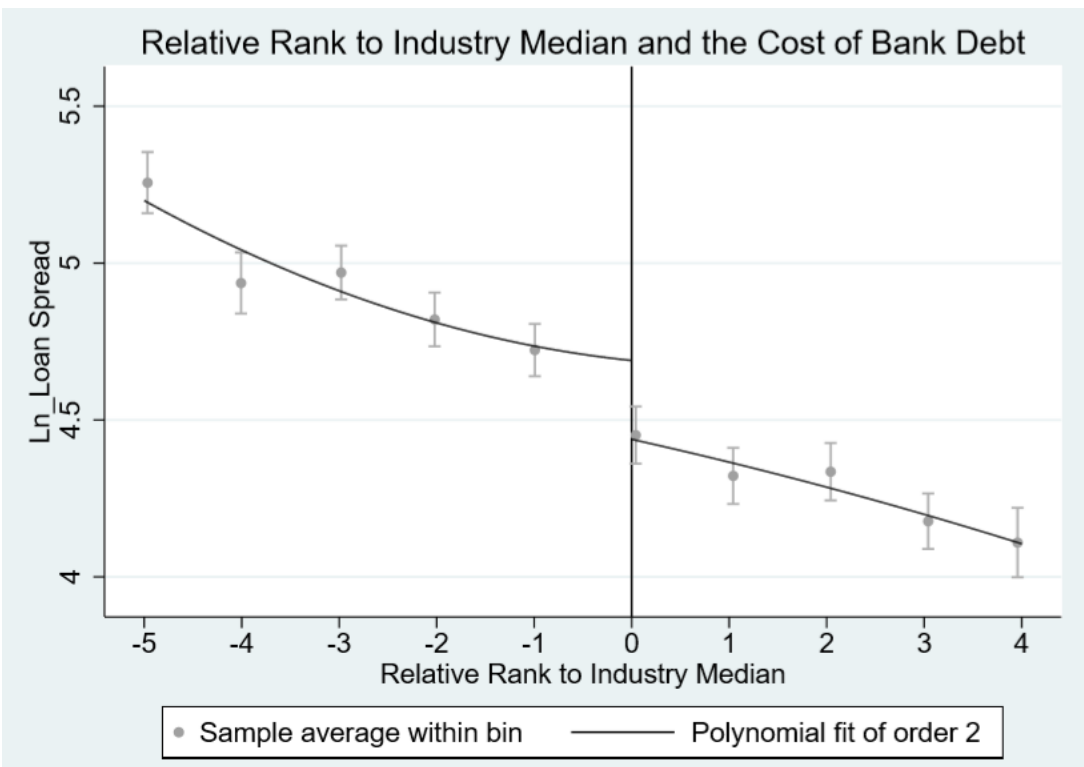


Table 1: Reputation summary statistics

This table presents summary statistics for this study's main reputation proxies. The sample includes 6,537 unique firm-year observations for firms in Fortune's list of America's Most Admired (MA) Companies for the years 20012012. Most Admired is an indicator variable equal to one if a firm appears on the MA list and zero otherwise. Score is the overall mean of a firm's scores on eight reputation attributes in current year. Rank is a firm's score-based rank within its industry in current year.

\begin{tabular}{lcccccc}
\hline & $\mathrm{N}$ & Mean & Std & P25 & Median & P75 \\
\hline Score & 6,537 & 6.04 & 1.04 & 5.37 & 6.07 & 6.78 \\
Rank & 6,537 & 5.42 & 3.12 & 3 & 5 & 8 \\
Most Admired "MA" & 6,537 & 0.54 & 0.50 & 0 & 1 & 1 \\
Contender & 6,537 & 0.46 & 0.50 & 0 & 0 & 1 \\
\hline
\end{tabular}


Table 2: Loan contract terms and firm characteristics summary statistics

This table presents summary statistics of loan contract terms and firm characteristics for the full sample as well as the two subsamples of Most Admired (MA) and non-MA firms. Panel A presents summary statistics of debt contract terms. Panel B provides summary statistics of firm characteristics. All variable definitions are in Appendix. Significance levels are denoted by *,**,***, which correspond to the $10 \%, 5 \%$, and $1 \%$ levels, respectively.

Panel A: Loan characteristics

\begin{tabular}{lcccccccc}
\hline & \multicolumn{2}{c}{ Full Sample } & \multicolumn{2}{c}{ MA firms } & \multicolumn{2}{c}{ Non-MA firms } & \multicolumn{2}{c}{ Difference } \\
& \multicolumn{2}{c}{$\mathrm{N}=20,104$} & \multicolumn{2}{c}{$\mathrm{N}=2,183$} & $\mathrm{~N}=17,921$ & & \\
& Mean & STD & Mean & STD & Mean & STD & Mean & $\mathrm{t}$ \\
\hline Loan spread (basis points) & 217.72 & 150.99 & 129.23 & 131.55 & 228.49 & 149.66 & $-99.27^{* * *}$ & -29.63 \\
Ln_spread & 5.12 & 0.78 & 4.40 & 1.00 & 5.21 & 0.71 & $-0.81^{* * *}$ & -48.53 \\
Loan size (\$millions) & 454.62 & 964.42 & 1122.60 & 1788.88 & 373.26 & 769.92 & $749.35^{* * *}$ & 35.32 \\
Maturity (months) & 48.24 & 21.71 & 42.30 & 23.32 & 48.97 & 21.4 & $-6.66^{* * *}$ & -13.60 \\
Syndicate dummy & 0.98 & 0.15 & 0.99 & 0.12 & 0.97 & 0.16 & $0.01^{* * *}$ & 3.17 \\
Security dummy & 0.55 & 0.50 & 0.22 & 0.41 & 0.59 & 0.49 & $-0.37^{* * *}$ & -33.54 \\
Annual fee (basis points) & 18.98 & 55.84 & 32.98 & 59.08 & 17.28 & 55.19 & $15.71^{* * *}$ & 12.46 \\
Upfront fee (basis points) & 47.10 & 127.30 & 26.87 & 95.18 & 49.57 & 130.46 & $-22.70^{* * *}$ & -7.88 \\
Performance pricing & 0.45 & 0.50 & 0.44 & 0.50 & 0.45 & 0.50 & -0.01 & -0.98 \\
Number of covenants & 1.40 & 1.35 & 0.82 & 1.03 & 1.47 & 1.37 & $-0.65^{* * *}$ & -21.48 \\
Covenant intensity & 2.02 & 2.13 & 0.95 & 1.55 & 2.15 & 2.16 & $-1.20^{* * *}$ & -25.19 \\
Number of lenders & 8.36 & 8.06 & 13.01 & 9.56 & 7.79 & 6.78 & $5.21^{* * *}$ & 29.14 \\
\hline
\end{tabular}

Panel B: Firm characteristics

\begin{tabular}{|c|c|c|c|c|c|c|c|c|}
\hline & \multicolumn{2}{|c|}{$\begin{array}{l}\text { Full Sample } \\
\mathrm{N}=12,277\end{array}$} & \multicolumn{2}{|c|}{$\begin{array}{l}\text { MA firms } \\
\mathrm{N}=1,326\end{array}$} & \multicolumn{2}{|c|}{$\begin{array}{l}\text { Non-MA firms } \\
\quad \mathrm{N}=10,951\end{array}$} & \multicolumn{2}{|c|}{ Difference } \\
\hline & Mean & STD & Mean & STD & Mean & STD & Mean & $\mathrm{t}$ \\
\hline Size & 7.37 & 1.80 & 9.50 & 1.34 & 7.11 & 1.67 & $2.39 * * *$ & 50.21 \\
\hline Age & 23.84 & 17.43 & 36.36 & 17.48 & 22.32 & 16.81 & $14.03 * * *$ & 28.59 \\
\hline $\mathrm{M} / \mathrm{B}$ & 2.55 & 3.75 & 3.50 & 3.75 & 2.44 & 3.74 & $1.07 * * *$ & 9.82 \\
\hline Tangibility & 0.31 & 0.26 & 0.29 & 0.23 & 0.31 & 0.26 & $-0.02 * * *$ & -2.88 \\
\hline Z-score & 1.61 & 1.28 & 2.00 & 1.19 & 1.56 & 1.29 & $0.44 * * *$ & 11.95 \\
\hline Cash & 0.07 & 0.09 & 0.06 & 0.07 & 0.08 & 0.09 & $-0.01 * * *$ & -5.61 \\
\hline Profitability & 0.03 & 0.10 & 0.05 & 0.07 & 0.02 & 0.10 & $0.03 * * *$ & 10.90 \\
\hline Sales growth & 0.13 & 0.35 & 0.09 & 0.23 & 0.14 & 0.36 & $-0.05 * * *$ & -4.78 \\
\hline Institutional ownership & 0.59 & 0.42 & 0.66 & 0.37 & 0.58 & 0.43 & $0.09 * * *$ & 7.14 \\
\hline Leverage & 0.38 & 0.25 & 0.39 & 0.23 & 0.38 & 0.26 & 0.01 & 1.09 \\
\hline $\mathrm{CF}$ volatility & 0.01 & 0.02 & 0.01 & 0.01 & 0.02 & 0.02 & $-0.01 * * *$ & -13.62 \\
\hline Bond Rating dummy & 0.93 & 0.26 & 0.91 & 0.29 & 0.46 & 0.50 & $0.45^{* * *}$ & 32.27 \\
\hline Investment grade dummy & 0.27 & 0.45 & 0.81 & 0.39 & 0.21 & 0.40 & $0.60 * * *$ & 50.61 \\
\hline
\end{tabular}


Table 3: Firm reputation and the cost of bank debt

This table reports regressions of the cost of bank debt on lagged firm reputation. The dependent variable is the Cost of bank debt, defined as the natural logarithm of loan spread for each loan. Most Admired is an indicator equal to one if the firm ranks on the "Most Admired" list, and zero otherwise. Score is the overall mean of a firm's scores on eight reputation attributes. Rank is a firm's score-based rank within its industry multiply by one. The remaining variable definitions are in the Appendix. Robust standard errors are clustered at the firm level and t-statistics are in parentheses. Significance levels are denoted by $*, * *, * * *$, which correspond to the $10 \%, 5 \%$, and $1 \%$ levels, respectively.

\begin{tabular}{|c|c|c|c|c|}
\hline & \multirow{2}{*}{$\begin{array}{c}\text { Full sample } \\
\text { (1) }\end{array}$} & \multicolumn{3}{|c|}{ Most Admired sample } \\
\hline & & (2) & (3) & (4) \\
\hline \multirow[t]{2}{*}{ Most Admired dummy } & $-0.144 * * *$ & $-0.144 * * *$ & & \\
\hline & $(-5.216)$ & $(-3.648)$ & & \\
\hline \multirow[t]{2}{*}{ Score } & & & $-0.098 * * *$ & \\
\hline & & & $(-4.154)$ & \\
\hline \multirow[t]{2}{*}{ Rank } & & & & $-0.025 * * *$ \\
\hline & & & & $(-3.028)$ \\
\hline \multirow[t]{2}{*}{ Firm size } & -0.018 & 0.061 & 0.065 & 0.061 \\
\hline & $(-1.116)$ & (1.102) & (1.191) & $(1.092)$ \\
\hline \multirow[t]{2}{*}{ Firm age } & $-0.263 * * *$ & $-0.760 * * *$ & $-0.810 * * *$ & $-0.760 * * *$ \\
\hline & $(-5.066)$ & $(-3.690)$ & $(-4.036)$ & $(-3.726)$ \\
\hline \multirow[t]{2}{*}{ Market-to-book } & -0.000 & -0.002 & -0.001 & -0.002 \\
\hline & $(-0.047)$ & $(-0.443)$ & $(-0.301)$ & $(-0.609)$ \\
\hline \multirow[t]{2}{*}{ Tangibility } & -0.110 & -0.033 & -0.084 & -0.015 \\
\hline & $(-0.992)$ & $(-0.112)$ & $(-0.293)$ & $(-0.052)$ \\
\hline \multirow[t]{2}{*}{ Z-score } & $-0.049 * * *$ & $-0.062 * *$ & $-0.063 * *$ & $-0.058 * *$ \\
\hline & $(-6.013)$ & $(-2.326)$ & $(-2.449)$ & $(-2.230)$ \\
\hline \multirow[t]{2}{*}{ Profitability } & $-0.420 * * *$ & $-0.963 * * *$ & $-0.807 * * *$ & $-0.930 * * *$ \\
\hline & $(-5.548)$ & $(-4.154)$ & $(-3.497)$ & $(-3.983)$ \\
\hline \multirow[t]{2}{*}{ Cash } & 0.019 & 0.077 & 0.001 & 0.067 \\
\hline & $(0.165)$ & $(0.232)$ & $(0.002)$ & $(0.201)$ \\
\hline \multirow[t]{2}{*}{ Sales growth } & 0.010 & 0.043 & 0.053 & 0.040 \\
\hline & $(0.642)$ & $(0.795)$ & $(0.961)$ & $(0.749)$ \\
\hline \multirow[t]{2}{*}{ Institutional ownership } & $-0.086 * * *$ & -0.112 & -0.102 & -0.108 \\
\hline & $(-3.048)$ & $(-1.471)$ & $(-1.400)$ & $(-1.465)$ \\
\hline \multirow[t]{2}{*}{ Leverage } & $0.238 * * *$ & $0.427 * * *$ & $0.383 * *$ & $0.434 * * *$ \\
\hline & $(4.945)$ & $(2.656)$ & $(2.459)$ & $(2.715)$ \\
\hline \multirow[t]{2}{*}{ Credit rating } & $-0.101 * * *$ & -0.044 & -0.049 & -0.054 \\
\hline & $(-4.205)$ & $(-0.562)$ & $(-0.641)$ & $(-0.705)$ \\
\hline \multirow[t]{2}{*}{ Lending relationship } & $-0.145^{* * *}$ & $-0.499 * *$ & $-0.494 * *$ & $-0.477 * *$ \\
\hline & $(-3.043)$ & $(-2.480)$ & $(-2.439)$ & $(-2.287)$ \\
\hline \multirow[t]{2}{*}{ Performance pricing } & $-0.112 * * *$ & $-0.066 * *$ & $-0.065 * *$ & $-0.067 * *$ \\
\hline & $(-9.423)$ & $(-2.187)$ & $(-2.160)$ & $(-2.224)$ \\
\hline \multirow[t]{2}{*}{ Maturity } & 0.010 & -0.019 & -0.022 & -0.019 \\
\hline & $(0.886)$ & $(-0.791)$ & $(-0.919)$ & $(-0.819)$ \\
\hline \multirow[t]{2}{*}{ Loan size } & $-0.118 * * *$ & $-0.196 * * *$ & $-0.197 * * *$ & $-0.196 * * *$ \\
\hline & $(-13.184)$ & $(-10.478)$ & $(-10.465)$ & $(-10.415)$ \\
\hline \multirow[t]{2}{*}{ CF volatility } & 0.630 & 3.216 & 3.013 & 3.104 \\
\hline & $(0.984)$ & $(1.093)$ & (1.094) & $(1.091)$ \\
\hline \multirow[t]{2}{*}{ Syndicate } & 0.039 & 0.043 & 0.061 & 0.057 \\
\hline & (1.048) & $(0.392)$ & $(0.551)$ & $(0.510)$ \\
\hline Loan Type \& Purpose & Yes & Yes & Yes & Yes \\
\hline Firm FE \& Year FE & Yes & Yes & Yes & Yes \\
\hline $\mathrm{N}$ & 18,939 & 3,830 & 3,830 & 3,830 \\
\hline Adjusted R2 & 0.705 & 0.760 & 0.761 & 0.760 \\
\hline
\end{tabular}


Table 4: Firm reputation and covenant intensity

The table presents regression of non-price terms on lagged firm reputation. The dependent variable is Covenant intensity, defined as the sum of six covenant indicators: collateral, dividend restriction, more than two financial covenants, asset sales sweep, equity issuance sweep, and debt issuance sweep. Most Admired is an indicator equal to one if the firm ranks on the "Most Admired" list, and zero otherwise. Score is the overall mean of a firm's scores on eight reputation attributes. Rank is a firm's score-based rank within its industry multiply by one. The remaining variable definitions are in Appendix. Robust standard errors are clustered at the firm level and t-statistics are in parentheses. Significance levels are denoted by *,**,***, which correspond to the $10 \%, 5 \%$, and $1 \%$ levels, respectively.

\begin{tabular}{|c|c|c|c|c|}
\hline & \multirow{2}{*}{$\begin{array}{c}\text { Full sample } \\
\text { (1) }\end{array}$} & \multicolumn{3}{|c|}{ Most Admired sample } \\
\hline & & (2) & (3) & (4) \\
\hline Most Admired dummy & $\begin{array}{l}-0.116^{*} \\
(-1.773)\end{array}$ & $\begin{array}{l}-0.117^{*} \\
(-1.798)\end{array}$ & & \\
\hline Score & & & $\begin{array}{c}-0.135 * * \\
(-2.147)\end{array}$ & \\
\hline Rank & & & & $\begin{array}{l}-0.012^{*} \\
(-1.681)\end{array}$ \\
\hline Firm size & $\begin{array}{c}-0.155^{* *} \\
(-2.575)\end{array}$ & $\begin{array}{l}-0.276^{*} \\
(-1.792)\end{array}$ & $\begin{array}{l}-0.258^{*} \\
(-1.706)\end{array}$ & $\begin{array}{l}-0.283^{*} \\
(-1.850)\end{array}$ \\
\hline Firm age & $\begin{array}{l}-0.315^{*} \\
(-1.887)\end{array}$ & $\begin{array}{c}-0.714 \\
(-0.949)\end{array}$ & $\begin{array}{c}-0.799 \\
(-1.061)\end{array}$ & $\begin{array}{c}-0.704 \\
(-0.940)\end{array}$ \\
\hline Market-to-book & $\begin{array}{c}0.005 \\
(0.693)\end{array}$ & $\begin{array}{c}-0.007 \\
(-0.894)\end{array}$ & $\begin{array}{c}-0.005 \\
(-0.741)\end{array}$ & $\begin{array}{c}-0.007 \\
(-0.960)\end{array}$ \\
\hline Tangibility & $\begin{array}{c}-0.540 \\
(-1.618)\end{array}$ & $\begin{array}{l}0.131 \\
(0.176)\end{array}$ & $\begin{array}{c}0.056 \\
(0.075)\end{array}$ & $\begin{array}{c}0.143 \\
(0.192)\end{array}$ \\
\hline Z-score & $\begin{array}{l}-0.104 * * \\
(-2.020)\end{array}$ & $\begin{array}{c}-0.057 \\
(-0.634)\end{array}$ & $\begin{array}{c}-0.042 \\
(-0.470)\end{array}$ & $\begin{array}{c}-0.062 \\
(-0.674)\end{array}$ \\
\hline Profitability & $\begin{array}{l}-0.584^{*} \\
(-1.676)\end{array}$ & $\begin{array}{c}-1.006 \\
(-1.418)\end{array}$ & $\begin{array}{l}-0.763 \\
(-1.033)\end{array}$ & $\begin{array}{l}-1.006 \\
(-1.407)\end{array}$ \\
\hline Cash & $\begin{array}{c}0.274 \\
(0.681)\end{array}$ & $\begin{array}{c}0.228 \\
(0.271)\end{array}$ & $\begin{array}{c}0.102 \\
(0.125)\end{array}$ & $\begin{array}{c}0.234 \\
(0.281)\end{array}$ \\
\hline Sales growth & $\begin{array}{c}0.006 \\
(0.089)\end{array}$ & $\begin{array}{c}0.009 \\
(0.069)\end{array}$ & $\begin{array}{c}0.031 \\
(0.232)\end{array}$ & $\begin{array}{c}0.004 \\
(0.028)\end{array}$ \\
\hline Institutional ownership & $\begin{array}{c}-0.161 \\
(-1.481)\end{array}$ & $\begin{array}{c}-0.065 \\
(-0.279)\end{array}$ & $\begin{array}{c}-0.048 \\
(-0.212)\end{array}$ & $\begin{array}{c}-0.065 \\
(-0.279)\end{array}$ \\
\hline Leverage & $\begin{array}{c}-0.296 \\
(-1.613)\end{array}$ & $\begin{array}{c}-0.235 \\
(-0.630)\end{array}$ & $\begin{array}{c}-0.312 \\
(-0.848)\end{array}$ & $\begin{array}{c}-0.222 \\
(-0.595)\end{array}$ \\
\hline Credit rating & $\begin{array}{l}-0.190^{*} \\
(-1.898)\end{array}$ & $\begin{array}{c}-0.393 \\
(-1.582)\end{array}$ & $\begin{array}{l}-0.390 \\
(-1.583)\end{array}$ & $\begin{array}{c}-0.403 \\
(-1.631)\end{array}$ \\
\hline Lending relationship & $\begin{array}{c}0.315 \\
(1.414)\end{array}$ & $\begin{array}{c}0.461 \\
(1.110)\end{array}$ & $\begin{array}{c}0.462 \\
(1.114)\end{array}$ & $\begin{array}{c}0.475 \\
(1.143)\end{array}$ \\
\hline Performance pricing & $\begin{array}{l}1.385 * * * \\
(32.760)\end{array}$ & $\begin{array}{c}0.946 * * * \\
(11.136)\end{array}$ & $\begin{array}{c}0.949 * * * \\
(11.248)\end{array}$ & $\begin{array}{c}0.945^{* * * *} \\
(11.112)\end{array}$ \\
\hline Maturity & $\begin{array}{c}-0.055 \\
(-1.576)\end{array}$ & $\begin{array}{c}-0.193 * * * \\
(-3.126)\end{array}$ & $\begin{array}{c}-0.196 * * * \\
(-3.184)\end{array}$ & $\begin{array}{c}-0.194 * * * \\
(-3.144)\end{array}$ \\
\hline Loan size & $\begin{array}{c}0.119 * * * \\
(6.908)\end{array}$ & $\begin{array}{c}0.084 * * * \\
(3.210)\end{array}$ & $\begin{array}{c}0.083 * * * \\
(3.148)\end{array}$ & $\begin{array}{c}0.084 * * * \\
(3.188)\end{array}$ \\
\hline CF volatility & $\begin{array}{l}1.036 \\
(0.455)\end{array}$ & $\begin{array}{c}4.746 \\
(0.658)\end{array}$ & $\begin{array}{l}4.408 \\
(0.633)\end{array}$ & $\begin{array}{c}4.724 \\
(0.663)\end{array}$ \\
\hline Syndicate & $\begin{array}{c}0.333 * * * \\
(2.893) \\
\end{array}$ & $\begin{array}{c}-0.275 \\
(-1.335) \\
\end{array}$ & $\begin{array}{c}-0.254 \\
(-1.218) \\
\end{array}$ & $\begin{array}{c}-0.266 \\
(-1.291) \\
\end{array}$ \\
\hline Loan Type \& Purpose & Yes & Yes & Yes & Yes \\
\hline Firm FE \& Year FE & Yes & Yes & Yes & Yes \\
\hline $\mathrm{N}$ & 18,939 & 3,830 & 3,830 & 3,830 \\
\hline Adjusted R2 & 0.542 & 0.563 & 0.565 & 0.563 \\
\hline
\end{tabular}


Table 5: Firm reputation and loan securitization

The table presents regression of non-pricing terms on lagged firm reputation. The dependent variable is Loan securitization, defined as an indicator equal to one if the loan facility is secured by collateral and zero otherwise. Most Admired is an indicator equal to one if the firm ranks on the "Most Admired" list, and zero otherwise. Score is the overall mean of a firm's scores on eight reputation attributes. Rank is a firm's score-based rank within its industry multiply by one. The remaining variable definitions are in Appendix. Robust standard errors are clustered at the firm level and t-statistics are in parentheses. Significance levels are denoted by *,**,***, which correspond to the $10 \%$, $5 \%$, and $1 \%$ levels, respectively.

\begin{tabular}{|c|c|c|c|c|}
\hline \multirow{3}{*}{ Most Admired dummy } & \multirow{4}{*}{$\begin{array}{c}\text { Full sample } \\
(1) \\
-0.058^{* * *} \\
(-3.449)\end{array}$} & \multicolumn{3}{|c|}{ Most Admired sample } \\
\hline & & (2) & (3) & (4) \\
\hline & & $\begin{array}{c}-0.055^{* *} \\
(-2.210)\end{array}$ & & \\
\hline Score & & & $\begin{array}{c}-0.033 * * * \\
(-2.253)\end{array}$ & \\
\hline Rank & & & & $\begin{array}{l}-0.009^{*} \\
(-1.885)\end{array}$ \\
\hline Firm size & $\begin{array}{c}-0.054 * * * \\
(-4.196)\end{array}$ & $\begin{array}{c}-0.060 \\
(-1.466)\end{array}$ & $\begin{array}{c}-0.060 \\
(-1.485)\end{array}$ & $\begin{array}{c}-0.060 \\
(-1.504)\end{array}$ \\
\hline Firm age & $\begin{array}{c}0.036 \\
(0.926)\end{array}$ & $\begin{array}{c}-0.020 \\
(-0.127)\end{array}$ & $\begin{array}{c}-0.033 \\
(-0.212)\end{array}$ & $\begin{array}{c}-0.019 \\
(-0.121)\end{array}$ \\
\hline Market-to-book & $\begin{array}{c}0.000 \\
(0.009)\end{array}$ & $\begin{array}{c}0.001 \\
(0.234)\end{array}$ & $\begin{array}{c}0.001 \\
(0.304)\end{array}$ & $\begin{array}{c}0.000 \\
(0.152)\end{array}$ \\
\hline Tangibility & $\begin{array}{l}-0.133^{*} \\
(-1.807)\end{array}$ & $\begin{array}{c}0.248 \\
(1.130)\end{array}$ & $\begin{array}{c}0.232 \\
(1.047)\end{array}$ & $\begin{array}{c}0.255 \\
(1.171)\end{array}$ \\
\hline Z-score & $\begin{array}{c}-0.026^{* * *} \\
(-2.512)\end{array}$ & $\begin{array}{c}-0.005 \\
(-0.188)\end{array}$ & $\begin{array}{c}-0.004 \\
(-0.169)\end{array}$ & $\begin{array}{c}-0.004 \\
(-0.172)\end{array}$ \\
\hline Profitability & $\begin{array}{c}-0.218 * * * \\
(-3.680)\end{array}$ & $\begin{array}{c}-0.331 * * \\
(-1.966)\end{array}$ & $\begin{array}{l}-0.281^{*} \\
(-1.665)\end{array}$ & $\begin{array}{l}-0.320^{*} \\
(-1.908)\end{array}$ \\
\hline Cash & $\begin{array}{c}0.017 \\
(0.195)\end{array}$ & $\begin{array}{c}0.086 \\
(0.381)\end{array}$ & $\begin{array}{c}0.063 \\
(0.282)\end{array}$ & $\begin{array}{c}0.084 \\
(0.371)\end{array}$ \\
\hline Sales growth & $\begin{array}{c}0.004 \\
(0.279)\end{array}$ & $\begin{array}{c}0.040 \\
(1.126)\end{array}$ & $\begin{array}{c}0.043 \\
(1.193)\end{array}$ & $\begin{array}{c}0.039 \\
(1.084)\end{array}$ \\
\hline Institutional ownership & $\begin{array}{c}-0.027 \\
(-1.318)\end{array}$ & $\begin{array}{c}-0.012 \\
(-0.300)\end{array}$ & $\begin{array}{c}-0.009 \\
(-0.220)\end{array}$ & $\begin{array}{c}-0.011 \\
(-0.269)\end{array}$ \\
\hline Leverage & $\begin{array}{c}0.111 * * * \\
(3.133)\end{array}$ & $\begin{array}{c}0.109 \\
(1.076)\end{array}$ & $\begin{array}{c}0.096 \\
(0.948)\end{array}$ & $\begin{array}{c}0.112 \\
(1.105)\end{array}$ \\
\hline Credit rating & $\begin{array}{c}-0.046 * * \\
(-2.340)\end{array}$ & $\begin{array}{l}-0.094^{*} \\
(-1.671)\end{array}$ & $\begin{array}{l}-0.097 * \\
(-1.711)\end{array}$ & $\begin{array}{l}-0.098^{*} \\
(-1.730)\end{array}$ \\
\hline Lending relationship & $\begin{array}{c}-0.045 \\
(-1.135)\end{array}$ & $\begin{array}{c}-0.140 \\
(-0.897)\end{array}$ & $\begin{array}{c}-0.138 \\
(-0.874)\end{array}$ & $\begin{array}{c}-0.132 \\
(-0.830)\end{array}$ \\
\hline Performance pricing & $\begin{array}{c}0.099 * * * \\
(11.023)\end{array}$ & $\begin{array}{c}0.012 \\
(0.621)\end{array}$ & $\begin{array}{l}0.013 \\
(0.642)\end{array}$ & $\begin{array}{c}0.012 \\
(0.603)\end{array}$ \\
\hline Maturity & $\begin{array}{c}0.031 * * * \\
(3.751)\end{array}$ & $\begin{array}{c}-0.007 \\
(-0.469)\end{array}$ & $\begin{array}{c}-0.008 \\
(-0.546)\end{array}$ & $\begin{array}{c}-0.007 \\
(-0.490)\end{array}$ \\
\hline Loan size & $\begin{array}{c}-0.015 * * * \\
(-2.904)\end{array}$ & $\begin{array}{c}-0.042 * * * \\
(-4.236)\end{array}$ & $\begin{array}{c}-0.042 * * * \\
(-4.265)\end{array}$ & $\begin{array}{c}-0.042 * * * \\
(-4.233)\end{array}$ \\
\hline CF volatility & $\begin{array}{c}1.057 * * \\
(2.428)\end{array}$ & $\begin{array}{c}3.309 * * \\
(2.356)\end{array}$ & $\begin{array}{l}3.246 * * \\
(2.419)\end{array}$ & $\begin{array}{c}3.271 * * \\
(2.412)\end{array}$ \\
\hline Syndicate & $\begin{array}{c}-0.055^{* * *} \\
(-2.371)\end{array}$ & $\begin{array}{c}-0.067 \\
(-1.266)\end{array}$ & $\begin{array}{c}-0.061 \\
(-1.153)\end{array}$ & $\begin{array}{c}-0.062 \\
(-1.169)\end{array}$ \\
\hline Loan Type \& Purpose & Yes & Yes & Yes & Yes \\
\hline Firm FE \& Year FE & Yes & Yes & Yes & Yes \\
\hline $\mathrm{N}$ & 18,939 & 3,830 & 3,830 & 3,830 \\
\hline Adjusted R2 & 0.573 & 0.570 & 0.570 & 0.570 \\
\hline
\end{tabular}




\section{Table 6: Propensity score matching}

This table examines the difference in loan contract terms across firms with good reputations and similar matched lessreputable firms. Panel A tabulates the means of the matching variables and propensity scores for the treatment and control groups (the differences across the two groups are not statistically significant at the $1 \%$ significance level). Panels B presents differences in Cost of bank debt, Covenant intensity, and Loan securitization means tests, respectively, controlling for firm characteristics using the nearest neighbor from a propensity score matching process based on logit regressions. The remaining variable definitions are in the Appendix. Robust standard errors are clustered at the firm level and $\mathrm{t}$-statistics are in parentheses. Significance levels are denoted by $*, * *, * * *$, which correspond to the $10 \%, 5 \%$, and $1 \%$ levels, respectively.

Panel A: Comparison of means across matched samples (Most Admired) in year t-1

\begin{tabular}{lcccc}
\hline & $\begin{array}{c}\text { Treatment } \\
(\text { Obs. }=3,280)\end{array}$ & $\begin{array}{c}\text { Control } \\
(\text { Obs. }=3,280)\end{array}$ & Difference & T-statistics \\
\hline Propensity score & 0.61 & 0.61 & 0.00 & 0.28 \\
Size & 9.64 & 9.73 & -0.09 & -1.09 \\
Age & 33.08 & 31.65 & 1.43 & 1.23 \\
M/B & 3.34 & 2.46 & 0.88 & 1.62 \\
Tangibility & 0.26 & 0.25 & 0.01 & 1.75 \\
Z-score & 2.00 & 2.00 & 0.00 & 0.09 \\
Cash & 2788.36 & 3034.55 & -246.19 & -1.29 \\
Profitability & 0.06 & 0.05 & 0.01 & 1.49 \\
Sales growth & 0.07 & 0.07 & 0.00 & 0.58 \\
Institutional ownership & 0.62 & 0.59 & 0.03 & 1.39 \\
Leverage & 0.39 & 0.39 & 0.00 & 0.12 \\
\hline
\end{tabular}

Panel B: Differences in means controlling for firm characteristics using propensity score matching

\begin{tabular}{lcccc}
\hline & \multicolumn{3}{c}{ Nearest one neighbor with common support } \\
\hline & $\begin{array}{c}\text { Treatment } \\
(\text { Obs. }=2,149)\end{array}$ & $\begin{array}{c}\text { Control } \\
(\text { Obs. }=2,169)\end{array}$ & Difference & T-statistics \\
\hline Cost of bank debt & 4.38 & 4.70 & $-0.32^{* * *}$ & -10.78 \\
Covenant intensity & 0.95 & 1.29 & $-0.33^{* * *}$ & -6.73 \\
Loan securitization & 0.22 & 0.32 & $-0.11^{* * *}$ & -8.10 \\
\hline
\end{tabular}


Table 7: Regression discontinuity analysis

The table presents the effect of being recognized as America's Most Admired Company on the cost of bank debt in the following year using the regression discontinuity analysis. The dependent variable is the Cost of bank debt, defined as the natural logarithm of loan spread for each loan. Most Admired is an indicator equal to one if the firm ranks on the "Most Admired" list, and zero otherwise. Relative rank is the within-industry rank relative to the industry median rank of zero. Most Admired*Relative rank is the interaction term between Most Admired and Relative rank. All variable definitions are in the Appendix. Significance levels are denoted by *,**,***, which correspond to the $10 \%$, $5 \%$, and $1 \%$ levels, respectively.

\begin{tabular}{lcccccc}
\hline & $(1)$ & $(2)$ & $(3)$ & $(4)$ & $(5)$ & $(6)$ \\
\hline Most Admired & $-0.250^{* * *}$ & $-0.265^{* * *}$ & $-0.184^{* * *}$ & $-0.186^{* * *}$ & $-0.196^{* * *}$ & $-0.202^{* * *}$ \\
& $(-3.407)$ & $(-3.500)$ & $(-3.311)$ & $(-3.334)$ & $(-3.632)$ & $(-3.793)$ \\
Relative rank & $-0.066^{* * *}$ & $-0.085^{* * *}$ & $-0.029^{* *}$ & $-0.032^{*}$ & -0.013 & -0.022 \\
& $(-4.443)$ & $(-4.119)$ & $(-2.479)$ & $(-1.852)$ & $(-1.053)$ & $(-1.080)$ \\
Most Admired*Relative rank & & 0.035 & & 0.006 & & 0.016 \\
& & $(1.194)$ & & $(0.274)$ & & $(0.665)$ \\
Firm Controls & No & No & Yes & Yes & Yes & Yes \\
Loan Controls & No & No & Yes & Yes & Yes & Yes \\
Industry FE & Yes & Yes & Yes & Yes & No & No \\
Firm FE & No & No & No & No & Yes & Yes \\
Year FE & Yes & Yes & Yes & Yes & Yes & Yes \\
N & 3,859 & 3,859 & 3,715 & 3,715 & 3,645 & 3,645 \\
Adjusted R2 & 0.474 & 0.475 & 0.653 & 0.653 & 0.768 & 0.768 \\
\hline
\end{tabular}


Table 8: Validity tests for regression discontinuity analysis

The table shows that the distribution of firm characteristics is smooth around the MA cutoff. For each characteristic, the first column presents the results of a local linear regression of each firm characteristic on Most Admired, Relative rank, Most Admired*Relative rank, and control variables. The estimated coefficients on Most Admired are reported in the first column, and t-statistics are reported in parentheses. Subsequent columns present the means of each characteristic for the two firms around the industry median cutoff: Relative rank=-1 and Relative rank=0, as well as the number of observations in these intervals. The last column presents the $p$-values for the difference in means test. All variable definitions are in Appendix. Significance levels are denoted by *,**,***, which correspond to the 10\%, $5 \%$, and $1 \%$ levels, respectively.

\begin{tabular}{|c|c|c|c|c|c|c|c|}
\hline & \multirow{2}{*}{$\begin{array}{c}\text { RD Most } \\
\text { Admired } \\
\text { coefficient } \\
\text { (1) }\end{array}$} & \multicolumn{2}{|c|}{$\begin{array}{c}\text { Just below cutoff } \\
\text { (Relative rank }=-1 \text { ) }\end{array}$} & \multicolumn{2}{|c|}{$\begin{array}{l}\text { Just above cutoff } \\
\text { (Relative rank }=0 \text { ) }\end{array}$} & \multirow{2}{*}{$\begin{array}{c}\text { Difference } \\
\text { (6) }\end{array}$} & \multirow{2}{*}{$\begin{array}{c}\text { p-value } \\
\text { (7) }\end{array}$} \\
\hline & & $\begin{array}{l}\text { Mean } \\
\text { (2) }\end{array}$ & $\begin{array}{c}\mathrm{N} \\
(3)\end{array}$ & $\begin{array}{c}\text { Mean } \\
\text { (4) }\end{array}$ & $\begin{array}{c}\mathrm{N} \\
(5)\end{array}$ & & \\
\hline Firm size & $\begin{array}{c}0.155 \\
(1.473)\end{array}$ & 8.938 & 444 & 9.270 & 440 & -0.332 & -1.578 \\
\hline Firm age & $\begin{array}{c}0.051 \\
(0.036)\end{array}$ & 36.018 & 444 & 34.584 & 440 & 1.434 & 1.205 \\
\hline Market-to-book & $\begin{array}{c}1.599 \\
(0.467)\end{array}$ & 2.341 & 444 & 3.716 & 440 & -1.374 & -0.834 \\
\hline Tangibility & $\begin{array}{c}0.019 \\
(1.588)\end{array}$ & 0.282 & 444 & 0.307 & 440 & -0.025 & -1.366 \\
\hline Z-score & $\begin{array}{c}-0.057 \\
(-0.833)\end{array}$ & 1.988 & 444 & 1.960 & 440 & 0.027 & 0.347 \\
\hline Profitability & $\begin{array}{l}0.003 \\
(0.635)\end{array}$ & 0.047 & 444 & 0.038 & 440 & 0.009 & 0.804 \\
\hline Cash & $\begin{array}{c}-0.005 \\
(-0.732)\end{array}$ & 0.056 & 444 & 0.057 & 440 & -0.001 & -0.176 \\
\hline Sales growth & $\begin{array}{c}-0.004 \\
(-0.136)\end{array}$ & 0.090 & 444 & 0.099 & 440 & -0.008 & -0.561 \\
\hline Institutional ownership & $\begin{array}{c}0.021 \\
(0.829)\end{array}$ & 0.651 & 444 & 0.643 & 440 & 0.008 & 0.294 \\
\hline Leverage & $\begin{array}{c}-0.028 \\
(-1.082)\end{array}$ & 0.422 & 444 & 0.418 & 440 & 0.004 & 0.239 \\
\hline CF volatility & $\begin{array}{c}0.000 \\
(0.494)\end{array}$ & 0.009 & 444 & 0.010 & 440 & -0.001 & -1.051 \\
\hline
\end{tabular}


Table 9: Correlations of Halo Index Variables

This table presents pairwise correlation coefficients between major reputation measures and the financial halo index variables. Most Admired is an indicator equal to one if the firm ranks on the "Most Admired" list, and zero otherwise. Score is the overall mean of a firm's scores on eight reputation attributes. Rank is the negative value of firm's score-based rank within its industry. All variables are defined in the Appendix. Significance levels are denoted by $*, * *, * * *$, which correspond to the $10 \%, 5 \%$, and $1 \%$ levels, respectively.

\begin{tabular}{|c|c|c|c|c|c|c|c|c|c|}
\hline & $\begin{array}{c}\text { Most } \\
\text { Admired }\end{array}$ & Score & Rank & Profitability & Sales growth & Leverage & $\begin{array}{c}\text { Lag } \\
\text { Profitability }\end{array}$ & $\begin{array}{l}\text { Market-to- } \\
\text { book }\end{array}$ & Sale \\
\hline Most Admired & 1.00 & & & & & & & & \\
\hline Score & $0.68 * * *$ & 1.00 & & & & & & & \\
\hline Rank & $0.80 * * *$ & $0.78 * * *$ & 1.00 & & & & & & \\
\hline Profitability & $0.09 * * *$ & $0.12 * * *$ & $0.10 * * *$ & 1.00 & & & & & \\
\hline Sales growth & $0.07 * * *$ & $0.15 * * *$ & $0.10 * * *$ & $0.14 * * *$ & 1.00 & & & & \\
\hline Leverage & $-0.12 * * *$ & $-0.23 * * *$ & $-0.16 * * *$ & $-0.19 * * *$ & $-0.13 * * *$ & 1.00 & & & \\
\hline Lag Profitability & $0.10 * * *$ & $0.15^{* * *}$ & $0.12 * * *$ & $0.18^{* * *}$ & $0.13^{* * *}$ & $-0.08 * * *$ & 1.00 & & \\
\hline Market-to-book & $0.05 * *$ & $0.07 * * *$ & $0.06^{* * *}$ & $0.04 *$ & 0.02 & 0.01 & $0.05 * * *$ & 1.00 & \\
\hline Sales & $0.18^{* * * *}$ & $0.21^{* * *}$ & $0.13^{* * * *}$ & $0.04^{* *}$ & $0.07^{* * * *}$ & $-0.08 * * *$ & $0.04^{* *}$ & -0.01 & 1.00 \\
\hline
\end{tabular}


Table 10: Removing financial performance from MA scores and ranks

This table reports regressions loan pricing on firm reputation using clean MA scores and ranks. Following Brown and Perry (1994), I estimate a model of MA scores (ranks) as a function of a halo index and use the residual from this model as the clean MA scores and ranks. The dependent variable is the Cost of bank debt in Models (1) and (2), Covenant intensity in Models (3) and (4), and Loan securitization in Models (5) and (6). Clean MA score (rank) is the residual from the estimation model that regresses raw MA score (rank) on five financial and operating variables: operating return on assets (contemporaneous and lagged one period), industry-adjusted market to book, sales growth, sales, and leverage. All variable definitions are in the Appendix. Significance levels are denoted by *,**,***, which correspond to the $10 \%, 5 \%$, and $1 \%$ levels, respectively.

\begin{tabular}{|c|c|c|c|c|c|c|}
\hline & \multicolumn{2}{|c|}{ Cost of bank debt } & \multicolumn{2}{|c|}{ Covenant intensity } & \multicolumn{2}{|c|}{ Loan securitization } \\
\hline & $(1)$ & $(2)$ & (3) & (4) & $(5)$ & (6) \\
\hline Clean MA score & $\begin{array}{c}-0.080 * * * \\
(-3.303)\end{array}$ & & $\begin{array}{l}-0.112^{*} \\
(-1.785)\end{array}$ & & $\begin{array}{l}-0.022 * \\
(-1.659)\end{array}$ & \\
\hline Clean MA rank & & $\begin{array}{c}-0.021 * * \\
(-2.519)\end{array}$ & & $\begin{array}{c}-0.005 \\
(-0.249)\end{array}$ & & $\begin{array}{c}-0.006 \\
(-1.289)\end{array}$ \\
\hline Firm size & $\begin{array}{c}0.053 \\
(0.922)\end{array}$ & $\begin{array}{c}0.050 \\
(0.842)\end{array}$ & $\begin{array}{l}-0.316^{*} \\
(-1.963)\end{array}$ & $\begin{array}{l}-0.346 * * \\
(-2.136)\end{array}$ & $\begin{array}{l}-0.074 * \\
(-1.746)\end{array}$ & $\begin{array}{l}-0.075^{*} \\
(-1.760)\end{array}$ \\
\hline Firm age & $\begin{array}{c}-0.753 * * * \\
(-3.587)\end{array}$ & $\begin{array}{c}-0.711 * * * \\
(-3.336)\end{array}$ & $\begin{array}{c}-0.652 \\
(-0.830)\end{array}$ & $\begin{array}{c}-0.568 \\
(-0.727)\end{array}$ & $\begin{array}{c}-0.003 \\
(-0.021)\end{array}$ & $\begin{array}{c}0.006 \\
(0.037)\end{array}$ \\
\hline Market-to-book & $\begin{array}{c}-0.002 \\
(-0.492)\end{array}$ & $\begin{array}{c}-0.002 \\
(-0.669)\end{array}$ & $\begin{array}{c}-0.006 \\
(-0.779)\end{array}$ & $\begin{array}{c}-0.007 \\
(-0.917)\end{array}$ & $\begin{array}{c}0.000 \\
(0.090)\end{array}$ & $\begin{array}{c}0.000 \\
(0.016)\end{array}$ \\
\hline Tangibility & $\begin{array}{c}-0.071 \\
(-0.238)\end{array}$ & $\begin{array}{c}-0.029 \\
(-0.095)\end{array}$ & $\begin{array}{c}-0.092 \\
(-0.124)\end{array}$ & $\begin{array}{c}-0.061 \\
(-0.082)\end{array}$ & $\begin{array}{c}0.217 \\
(0.972)\end{array}$ & $\begin{array}{c}0.229 \\
(1.037)\end{array}$ \\
\hline Z-score & $\begin{array}{c}0.038 \\
(0.972)\end{array}$ & $\begin{array}{c}0.037 \\
(0.903)\end{array}$ & $\begin{array}{c}-0.062 \\
(-0.669)\end{array}$ & $\begin{array}{c}-0.086 \\
(-0.915)\end{array}$ & $\begin{array}{c}-0.014 \\
(-0.519)\end{array}$ & $\begin{array}{c}-0.014 \\
(-0.517)\end{array}$ \\
\hline Profitability & $\begin{array}{c}-0.950 * * * \\
(-4.149)\end{array}$ & $\begin{array}{c}-1.027 * * * \\
(-4.385)\end{array}$ & $\begin{array}{l}-1.219 * \\
(-1.768)\end{array}$ & $\begin{array}{c}-1.369 * * \\
(-2.031)\end{array}$ & $\begin{array}{l}-0.327 * \\
(-1.889)\end{array}$ & $\begin{array}{c}-0.347 * * \\
(-2.007)\end{array}$ \\
\hline Cash & $\begin{array}{c}-0.017 \\
(-0.053)\end{array}$ & $\begin{array}{c}0.045 \\
(0.133)\end{array}$ & $\begin{array}{c}-0.089 \\
(-0.108)\end{array}$ & $\begin{array}{c}0.038 \\
(0.045)\end{array}$ & $\begin{array}{c}0.028 \\
(0.128)\end{array}$ & $\begin{array}{c}0.044 \\
(0.202)\end{array}$ \\
\hline Sales growth & $\begin{array}{c}0.046 \\
(0.739)\end{array}$ & $\begin{array}{c}0.033 \\
(0.551)\end{array}$ & $\begin{array}{c}0.073 \\
(0.486)\end{array}$ & $\begin{array}{c}0.040 \\
(0.265)\end{array}$ & $\begin{array}{c}0.047 \\
(1.165)\end{array}$ & $\begin{array}{c}0.044 \\
(1.091)\end{array}$ \\
\hline Institutional ownership & $\begin{array}{c}-0.127 \\
(-1.628)\end{array}$ & $\begin{array}{l}-0.131^{*} \\
(-1.658)\end{array}$ & $\begin{array}{c}-0.069 \\
(-0.288)\end{array}$ & $\begin{array}{c}-0.080 \\
(-0.325)\end{array}$ & $\begin{array}{c}-0.023 \\
(-0.520)\end{array}$ & $\begin{array}{c}-0.024 \\
(-0.543)\end{array}$ \\
\hline Leverage & $\begin{array}{c}0.423 * * \\
(2.569)\end{array}$ & $\begin{array}{c}0.453 * * * \\
(2.693)\end{array}$ & $\begin{array}{c}-0.395 \\
(-1.031)\end{array}$ & $\begin{array}{c}-0.351 \\
(-0.909)\end{array}$ & $\begin{array}{c}0.105 \\
(1.004)\end{array}$ & $\begin{array}{c}0.113 \\
(1.086)\end{array}$ \\
\hline Credit rating & $\begin{array}{c}-0.045 \\
(-0.590)\end{array}$ & $\begin{array}{c}-0.048 \\
(-0.638)\end{array}$ & $\begin{array}{c}-0.350 \\
(-1.426)\end{array}$ & $\begin{array}{c}-0.364 \\
(-1.479)\end{array}$ & $\begin{array}{l}-0.099 * \\
(-1.725)\end{array}$ & $\begin{array}{l}-0.099 * \\
(-1.735)\end{array}$ \\
\hline Lending relationship & $\begin{array}{c}-0.476 * * \\
(-2.291)\end{array}$ & $\begin{array}{c}-0.463 * * \\
(-2.168)\end{array}$ & $\begin{array}{c}0.438 \\
(1.040)\end{array}$ & $\begin{array}{c}0.450 \\
(1.070)\end{array}$ & $\begin{array}{c}-0.155 \\
(-0.945)\end{array}$ & $\begin{array}{c}-0.151 \\
(-0.919)\end{array}$ \\
\hline Performance pricing & $\begin{array}{c}-0.070 * * \\
(-2.299)\end{array}$ & $\begin{array}{c}-0.072 * * \\
(-2.350)\end{array}$ & $\begin{array}{c}0.962 * * * \\
(11.224)\end{array}$ & $\begin{array}{c}0.958 * * * \\
(11.102)\end{array}$ & $\begin{array}{c}0.013 \\
(0.672)\end{array}$ & $\begin{array}{c}0.013 \\
(0.646)\end{array}$ \\
\hline Maturity & $\begin{array}{c}-0.021 \\
(-0.834)\end{array}$ & $\begin{array}{c}-0.018 \\
(-0.730)\end{array}$ & $\begin{array}{c}-0.203 * * * \\
(-3.226)\end{array}$ & $\begin{array}{c}-0.200 * * * \\
(-3.166)\end{array}$ & $\begin{array}{c}-0.007 \\
(-0.486)\end{array}$ & $\begin{array}{c}-0.007 \\
(-0.438)\end{array}$ \\
\hline Loan size & $\begin{array}{c}-0.200^{* * * *} \\
(-10.161)\end{array}$ & $\begin{array}{c}-0.199 * * * \\
(-10.131)\end{array}$ & $\begin{array}{c}0.082 * * * \\
(3.070)\end{array}$ & $\begin{array}{c}0.082 * * * \\
(3.099)\end{array}$ & $\begin{array}{c}-0.042 * * * \\
(-4.159)\end{array}$ & $\begin{array}{c}-0.041 * * * \\
(-4.141)\end{array}$ \\
\hline CF volatility & $\begin{array}{c}2.965 \\
(0.990)\end{array}$ & $\begin{array}{c}3.052 \\
(0.995)\end{array}$ & $\begin{array}{c}3.706 \\
(0.493)\end{array}$ & $\begin{array}{c}4.116 \\
(0.537)\end{array}$ & $\begin{array}{c}3.263 * * \\
(2.229)\end{array}$ & $\begin{array}{c}3.281 * * \\
(2.228)\end{array}$ \\
\hline Syndicate & $\begin{array}{c}0.069 \\
(0.613)\end{array}$ & $\begin{array}{c}0.065 \\
(0.576)\end{array}$ & $\begin{array}{c}-0.265 \\
(-1.281)\end{array}$ & $\begin{array}{c}-0.278 \\
(-1.354)\end{array}$ & $\begin{array}{c}-0.060 \\
(-1.130)\end{array}$ & $\begin{array}{c}-0.060 \\
(-1.142)\end{array}$ \\
\hline Loan Type \& Purpose & Yes & Yes & Yes & Yes & Yes & Yes \\
\hline Firm FE \& Year FE & Yes & Yes & Yes & Yes & Yes & Yes \\
\hline $\mathrm{N}$ & 3,721 & 3,721 & 3,721 & 3,721 & 3,721 & 3,721 \\
\hline Adjusted R2 & 0.761 & 0.760 & 0.559 & 0.558 & 0.565 & 0.565 \\
\hline
\end{tabular}




\section{Table 11: Reputation and future operating performance}

The table presents regressions of future operating cash flows on firm reputation. The dependent variable is Future Operating Cash flow in Model (1) and (2), Return Volatility in Model (3) and (4), Earning per Share (EPS) Volatility in Model (5) and (6), and Loan Covenant Violation Probability in Model (7) and (8). Score is the overall mean of a firm's scores on eight reputation attributes. Rank is a firm's score-based rank within its industry multiply by one. The remaining variable definitions are in the Appendix. Robust standard errors are clustered at the firm level and t-statistics are in parentheses. Significance levels are denoted by $*, * *, * * *$, which correspond to the $10 \%, 5 \%$, and $1 \%$ levels, respectively.

\begin{tabular}{|c|c|c|c|c|c|c|c|c|}
\hline \multirow[b]{3}{*}{ Score } & \multicolumn{2}{|c|}{ Future Operating Cash Flow } & \multicolumn{2}{|c|}{ Stock Return Volatility } & \multicolumn{2}{|c|}{ EPS volatility } & \multicolumn{2}{|c|}{$\begin{array}{c}\text { Loan Covenant Violation } \\
\text { Probability }\end{array}$} \\
\hline & (1) & (2) & (3) & (4) & (5) & (6) & (7) & $(8)$ \\
\hline & $\begin{array}{c}0.006 * * * \\
(4.793)\end{array}$ & & $\begin{array}{c}-0.006 * * * \\
(-5.839)\end{array}$ & & $\begin{array}{c}-0.050 * * * \\
(-2.761)\end{array}$ & & $\begin{array}{c}-0.036 * * \\
(-2.393)\end{array}$ & \\
\hline Rank & & $\begin{array}{c}0.002 * * * \\
(4.738)\end{array}$ & & $\begin{array}{r}-0.001 * * \\
(-2.459)\end{array}$ & & $\begin{array}{l}-0.007^{*} \\
(-1.722)\end{array}$ & & $\begin{array}{l}-0.008^{*} \\
(-1.694)\end{array}$ \\
\hline Firm size & $\begin{array}{c}0.000 \\
(0.261)\end{array}$ & $\begin{array}{c}0.001 \\
(0.631)\end{array}$ & $\begin{array}{c}-0.008 * * * \\
(-5.438)\end{array}$ & $\begin{array}{l}-0.007^{*} \\
(-1.758)\end{array}$ & $\begin{array}{l}-0.028 \\
(-1.586)\end{array}$ & $\begin{array}{c}-0.041^{* *} \\
(-2.124)\end{array}$ & $\begin{array}{l}0.032 * \\
(1.725)\end{array}$ & $\begin{array}{c}0.027 \\
(1.491)\end{array}$ \\
\hline Firm age & $\begin{array}{c}0.001 \\
(0.250)\end{array}$ & $\begin{array}{l}0.000 \\
(0.220)\end{array}$ & $\begin{array}{c}-0.005 * * \\
(-2.565)\end{array}$ & $\begin{array}{l}-0.005 * * \\
(-2.482)\end{array}$ & $\begin{array}{l}-0.002 \\
(-0.072)\end{array}$ & $\begin{array}{c}-0.003 \\
(-0.089)\end{array}$ & $\begin{array}{l}-0.017 \\
(-0.860)\end{array}$ & $\begin{array}{l}-0.015 \\
(-0.747)\end{array}$ \\
\hline Market-to-book & $\begin{array}{c}0.002 * * * \\
(4.767)\end{array}$ & $\begin{array}{c}0.002 * * * \\
(4.779)\end{array}$ & $\begin{array}{l}-0.000 \\
(-1.212)\end{array}$ & $\begin{array}{l}-0.000 \\
(-0.257)\end{array}$ & $\begin{array}{c}-0.002 \\
(-0.769)\end{array}$ & $\begin{array}{l}-0.003 \\
(-1.019)\end{array}$ & $\begin{array}{c}0.004 \\
(0.958)\end{array}$ & $\begin{array}{c}0.003 \\
(0.808)\end{array}$ \\
\hline Tangibility & $\begin{array}{c}0.085^{* * * *} \\
(6.822)\end{array}$ & $\begin{array}{c}0.086 * * * \\
(6.813)\end{array}$ & $\begin{array}{l}-0.012 \\
(-1.268)\end{array}$ & $\begin{array}{c}0.014 \\
(0.611)\end{array}$ & $\begin{array}{c}0.169 \\
(1.366)\end{array}$ & $\begin{array}{l}0.151 \\
(1.223)\end{array}$ & $\begin{array}{l}-0.255^{*} \\
(-1.938)\end{array}$ & $\begin{array}{c}-0.268 * * \\
(-2.069)\end{array}$ \\
\hline Z-score & $\begin{array}{c}0.019 * * * \\
(7.475)\end{array}$ & $\begin{array}{c}0.019 * * * \\
(7.400)\end{array}$ & $\begin{array}{c}-0.002 \\
(-1.049)\end{array}$ & $\begin{array}{c}0.001 \\
(0.266)\end{array}$ & $\begin{array}{l}0.001 \\
(0.037)\end{array}$ & $\begin{array}{c}-0.003 \\
(-0.113)\end{array}$ & $\begin{array}{l}-0.003 \\
(-0.143)\end{array}$ & $\begin{array}{l}-0.003 \\
(-0.144)\end{array}$ \\
\hline Profitability & $\begin{array}{l}0.256^{* * *} \\
(10.680)\end{array}$ & $\begin{array}{l}0.260 * * * \\
(10.698)\end{array}$ & $\begin{array}{c}-0.218 * * * \\
(-12.096)\end{array}$ & $\begin{array}{c}-0.167 * * * \\
(-8.271)\end{array}$ & $\begin{array}{c}-2.429 * * * \\
(-7.247)\end{array}$ & $\begin{array}{c}-2.487 * * * \\
(-7.444)\end{array}$ & $\begin{array}{c}-0.826 * * * \\
(-4.254)\end{array}$ & $\begin{array}{c}-0.899 * * * \\
(-4.738)\end{array}$ \\
\hline Cash & $\begin{array}{c}0.081 * * * \\
(4.028)\end{array}$ & $\begin{array}{c}0.077 * * * \\
(3.841)\end{array}$ & $\begin{array}{c}0.051^{* * *} * \\
(3.369)\end{array}$ & $\begin{array}{c}0.008 \\
(0.495)\end{array}$ & $\begin{array}{c}1.006 * * * \\
(4.285)\end{array}$ & $\begin{array}{c}1.041 * * * \\
(4.361)\end{array}$ & $\begin{array}{c}-0.040 \\
(-0.165)\end{array}$ & $\begin{array}{c}-0.001 \\
(-0.004)\end{array}$ \\
\hline Sales growth & $\begin{array}{c}0.002 \\
(0.515)\end{array}$ & $\begin{array}{c}0.002 \\
(0.503)\end{array}$ & $\begin{array}{c}-0.002 \\
(-0.430)\end{array}$ & $\begin{array}{c}-0.003 \\
(-0.858)\end{array}$ & $\begin{array}{c}-0.056 \\
(-0.847)\end{array}$ & $\begin{array}{c}-0.058 \\
(-0.870)\end{array}$ & $\begin{array}{l}-0.120^{*} \\
(-1.789)\end{array}$ & $\begin{array}{l}-0.130^{*} \\
(-1.929)\end{array}$ \\
\hline Leverage & $\begin{array}{c}0.028 * * * \\
(2.983) \\
\end{array}$ & $\begin{array}{c}0.026^{* * * *} \\
(2.736) \\
\end{array}$ & $\begin{array}{c}0.036 * * * \\
(4.507)\end{array}$ & $\begin{array}{c}0.018 \\
(1.453) \\
\end{array}$ & $\begin{array}{c}0.852 * * * \\
(4.760) \\
\end{array}$ & $\begin{array}{c}0.885 * * * \\
(4.858)\end{array}$ & $\begin{array}{c}0.265 * * * \\
(2.965) \\
\end{array}$ & $\begin{array}{c}0.286^{* * * *} \\
(3.221) \\
\end{array}$ \\
\hline Firm FE & Yes & Yes & Yes & Yes & Yes & Yes & Yes & Yes \\
\hline Year FE & Yes & Yes & Yes & Yes & Yes & Yes & Yes & Yes \\
\hline Loan Controls & No & No & No & No & No & No & Yes & Yes \\
\hline $\mathrm{N}$ & 5,693 & 5,693 & 5,693 & 5,693 & 5,693 & 5,693 & 1,820 & 1,820 \\
\hline Adjusted R2 & 0.770 & 0.770 & 0.705 & 0.705 & 0.475 & 0.474 & 0.399 & 0.397 \\
\hline
\end{tabular}


Table 12: Firm reputation and investment activities

This table reports regressions of investment activities on lagged firm reputation. The dependent variable is Capital expenditure in Panel A, and R\&D in Panel B. Both variables are scaled by total asset and multiplied by 100. Most Admired is an indicator equal to one if the firm ranks on the "Most Admired" list and zero otherwise. Score is the overall mean of a firm's scores on eight reputation attributes. Rank is a firm's score-based rank within its industry multiply by one. WithLoan Subsample includes firms that obtain at least one bank loan in prior year and Without-Loan Subsample includes firms that do not borrow in the prior year. Robust standard errors are clustered at the firm level and t-statistics are in parentheses. Significance levels are denoted by *,**,***, which correspond to the $10 \%$, $5 \%$, and $1 \%$ levels, respectively.

Panel A: Capital Expenditure

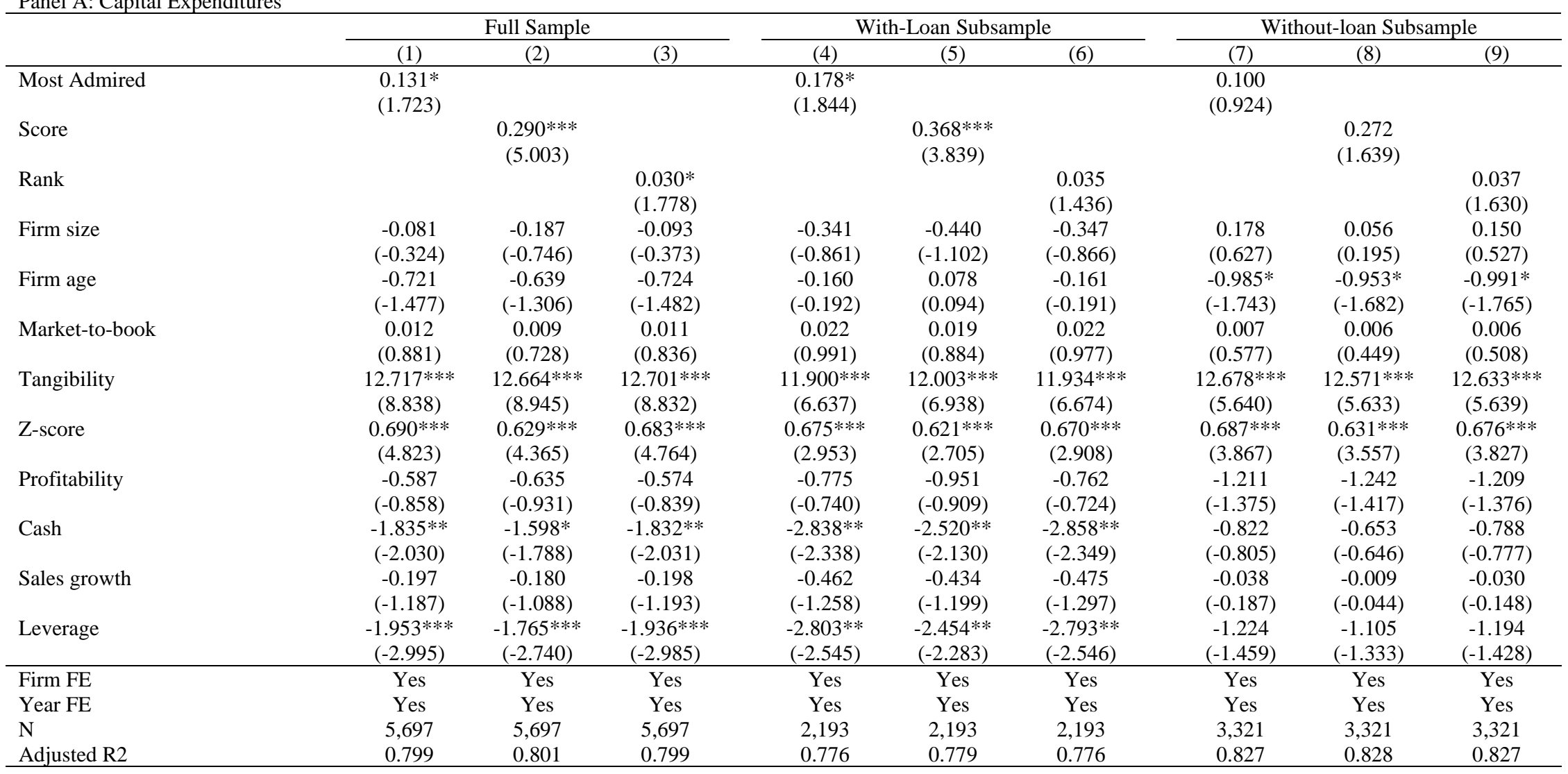


Panel B: Research \& Development

\begin{tabular}{|c|c|c|c|c|c|c|c|c|c|}
\hline & \multicolumn{3}{|c|}{ Full Sample } & \multicolumn{3}{|c|}{ With-Loan Subsample } & \multicolumn{3}{|c|}{ Without-loan Subsample } \\
\hline & (1) & (2) & (3) & (4) & (5) & (6) & (7) & $(8)$ & (9) \\
\hline Most Admired & $\begin{array}{c}0.246 * * \\
(2.261)\end{array}$ & & & $\begin{array}{c}0.119 * * \\
(2.017)\end{array}$ & & & $\begin{array}{c}-0.129 * * \\
(-2.012)\end{array}$ & & \\
\hline Score & & $\begin{array}{c}0.214 * * * \\
(3.087)\end{array}$ & & & $\begin{array}{c}0.047 * * \\
(1.968)\end{array}$ & & & $\begin{array}{c}-0.022 \\
(-0.548)\end{array}$ & \\
\hline Rank & & & $\begin{array}{c}0.047 * * \\
(2.155)\end{array}$ & & & $\begin{array}{c}0.026 * * \\
(2.030)\end{array}$ & & & $\begin{array}{c}-0.014 \\
(-0.748)\end{array}$ \\
\hline Firm size & $\begin{array}{c}0.023 \\
(0.203)\end{array}$ & $\begin{array}{c}-0.015 \\
(-0.128)\end{array}$ & $\begin{array}{c}0.022 \\
(0.192)\end{array}$ & $\begin{array}{c}-0.361 * * * \\
(-3.391)\end{array}$ & $\begin{array}{c}-0.352 * * * \\
(-3.261)\end{array}$ & $\begin{array}{c}-0.369 * * * \\
(-3.379)\end{array}$ & $\begin{array}{c}-0.858 * * * \\
(-2.802)\end{array}$ & $\begin{array}{c}-0.868 * * * \\
(-2.827)\end{array}$ & $\begin{array}{c}-0.862 * * * \\
(-2.907)\end{array}$ \\
\hline Firm age & $\begin{array}{c}-0.105 \\
(-0.849)\end{array}$ & $\begin{array}{c}-0.113 \\
(-0.918)\end{array}$ & $\begin{array}{c}-0.113 \\
(-0.910)\end{array}$ & $\begin{array}{c}0.688 \\
(1.614)\end{array}$ & $\begin{array}{c}0.700 \\
(1.636)\end{array}$ & $\begin{array}{c}0.690 \\
(1.610)\end{array}$ & $\begin{array}{c}0.002 \\
(0.006)\end{array}$ & $\begin{array}{c}0.004 \\
(0.013)\end{array}$ & $\begin{array}{c}0.008 \\
(0.026)\end{array}$ \\
\hline Market-to-book & $\begin{array}{c}0.049 * * * \\
(3.268)\end{array}$ & $\begin{array}{c}0.047 * * * \\
(3.138)\end{array}$ & $\begin{array}{c}0.049 * * * \\
(3.217)\end{array}$ & $\begin{array}{c}0.018 * * \\
(2.008)\end{array}$ & $\begin{array}{c}0.019 * * \\
(2.056)\end{array}$ & $\begin{array}{c}0.018 * * \\
(2.006)\end{array}$ & $\begin{array}{c}0.006 \\
(1.033)\end{array}$ & $\begin{array}{c}0.006 \\
(1.015)\end{array}$ & $\begin{array}{c}0.006 \\
(1.053)\end{array}$ \\
\hline Tangibility & $\begin{array}{c}0.902 \\
(1.441)\end{array}$ & $\begin{array}{c}0.877 \\
(1.406)\end{array}$ & $\begin{array}{c}0.921 \\
(1.475)\end{array}$ & $\begin{array}{l}0.989^{*} \\
(1.898)\end{array}$ & $\begin{array}{l}1.043 * * \\
(1.997)\end{array}$ & $\begin{array}{l}1.008 * \\
(1.940)\end{array}$ & $\begin{array}{c}-0.739 \\
(-0.352)\end{array}$ & $\begin{array}{c}-0.733 \\
(-0.349)\end{array}$ & $\begin{array}{c}-0.723 \\
(-0.349)\end{array}$ \\
\hline Z-score & $\begin{array}{c}-0.220 \\
(-1.493)\end{array}$ & $\begin{array}{c}-0.234 \\
(-1.580)\end{array}$ & $\begin{array}{c}-0.226 \\
(-1.537)\end{array}$ & $\begin{array}{c}0.023 \\
(0.278)\end{array}$ & $\begin{array}{c}0.023 \\
(0.285)\end{array}$ & $\begin{array}{c}0.018 \\
(0.216)\end{array}$ & $\begin{array}{c}-0.119 \\
(-0.696)\end{array}$ & $\begin{array}{c}-0.118 \\
(-0.679)\end{array}$ & $\begin{array}{c}-0.117 \\
(-0.691)\end{array}$ \\
\hline Profitability & $\begin{array}{c}-1.552 \\
(-1.189)\end{array}$ & $\begin{array}{c}-1.791 \\
(-1.366)\end{array}$ & $\begin{array}{l}-1.590 \\
(-1.226)\end{array}$ & $\begin{array}{c}-1.133 \\
(-1.580)\end{array}$ & $\begin{array}{c}-1.126 \\
(-1.580)\end{array}$ & $\begin{array}{c}-1.127 \\
(-1.575)\end{array}$ & $\begin{array}{c}-1.899 * * \\
(-2.364)\end{array}$ & $\begin{array}{c}-1.907 * * \\
(-2.370)\end{array}$ & $\begin{array}{c}-1.907 * * \\
(-2.367)\end{array}$ \\
\hline Cash & $\begin{array}{c}6.566 * * * \\
(3.345)\end{array}$ & $\begin{array}{c}6.734 * * * \\
(3.411)\end{array}$ & $\begin{array}{c}6.604 * * * \\
(3.363)\end{array}$ & $\begin{array}{c}0.225 \\
(0.237)\end{array}$ & $\begin{array}{c}0.248 \\
(0.261)\end{array}$ & $\begin{array}{c}0.213 \\
(0.224)\end{array}$ & $\begin{array}{c}0.013 \\
(0.014)\end{array}$ & $\begin{array}{c}0.010 \\
(0.011)\end{array}$ & $\begin{array}{c}0.008 \\
(0.008)\end{array}$ \\
\hline Sales growth & $\begin{array}{c}-0.146 \\
(-0.765)\end{array}$ & $\begin{array}{c}-0.160 \\
(-0.843)\end{array}$ & $\begin{array}{c}-0.158 \\
(-0.826)\end{array}$ & $\begin{array}{c}0.320 * * \\
(2.330)\end{array}$ & $\begin{array}{c}0.310 * * \\
(2.266)\end{array}$ & $\begin{array}{c}0.311 * * \\
(2.287)\end{array}$ & $\begin{array}{c}0.016 \\
(0.140)\end{array}$ & $\begin{array}{c}0.021 \\
(0.180)\end{array}$ & $\begin{array}{c}0.018 \\
(0.160)\end{array}$ \\
\hline Leverage & $\begin{array}{c}-1.672 * * * \\
(-3.161)\end{array}$ & $\begin{array}{c}-1.549 * * * \\
(-3.031)\end{array}$ & $\begin{array}{c}-1.656^{* * * *} \\
(-3.138)\end{array}$ & $\begin{array}{c}-0.374 \\
(-1.121) \\
\end{array}$ & $\begin{array}{c}-0.352 \\
(-1.044)\end{array}$ & $\begin{array}{c}-0.364 \\
(-1.082) \\
\end{array}$ & $\begin{array}{c}-0.955^{* *} \\
(-2.082) \\
\end{array}$ & $\begin{array}{c}-0.937 * * \\
(-2.052) \\
\end{array}$ & $\begin{array}{c}-0.946^{* *} \\
(-2.062)\end{array}$ \\
\hline Firm FE & Yes & Yes & Yes & Yes & Yes & Yes & Yes & Yes & Yes \\
\hline Year FE & Yes & Yes & Yes & Yes & Yes & Yes & Yes & Yes & Yes \\
\hline $\mathrm{N}$ & 5,697 & 5,697 & 5,697 & 2,193 & 2,193 & 2,193 & 3,321 & 3,321 & 3,321 \\
\hline Adjusted R2 & 0.585 & 0.587 & 0.586 & 0.925 & 0.925 & 0.925 & 0.935 & 0.935 & 0.935 \\
\hline
\end{tabular}




\section{References}

Altman, E.I., 1968. Financial ratios, discriminant analysis and the prediction of corporate bankruptcy. Journal of Finance, 23(4), pp.589-609.

Anginer, D., Warburton, A.J. and Yildizhan, C., 2011. Corporate reputation and cost of debt. Working paper, The World Bank, Syracuse University, and University of Georgia.

Barclay, M.J. and Smith Jr, C.W., 1995. The maturity structure of corporate debt. the Journal of Finance, 50(2), pp.609-631.

Barnett, M.L., Jermier, J.M. and Lafferty, B.A., 2006. Corporate reputation: The definitional landscape. Corporate Reputation Review, 9(1), pp.26-38.

Barney, J., 1991. Firm resources and sustained competitive advantage. Journal of Management, 17(1), pp.99-120.

Barth, M.E., Konchitchki, Y. and Landsman, W.R., 2013. Cost of capital and earnings transparency. Journal of Accounting and Economics, 55(2-3), pp.206-224.

Bharath, S.T., Dahiya, S., Saunders, A. and Srinivasan, A., 2011. Lending relationships and loan contract terms. The Review of Financial Studies, 24(4), pp.1141-1203.

Bharath, S.T., Sunder, J. and Sunder, S.V., 2008. Accounting quality and debt contracting. The Accounting Review, 83(1), pp.1-28.

Bhojraj, S. and Sengupta, P., 2003. Effect of corporate governance on bond ratings and yields: The role of institutional investors and outside directors. Journal of Business, 76(3), pp.455-475.

Bond, S., Harhoff, D. and Van Reenen, J., 1999. Investment, $R \& D$ and Financial Constraints in Britain and Germany (No. W99/05). London: Institute for Fiscal Studies.

Bradley, M. and Roberts, M.R., 2015. The structure and pricing of corporate debt covenants. Quarterly Journal of Finance, 5(2), pp.1-37.

Brickley, J.A., Linck, J.S. and Coles, J.L., 1999. What happens to CEOs after they retire? New evidence on career concerns, horizon problems, and CEO incentives. Journal of Financial Economics, 52(3), pp.341-377.

Brown, B. and Perry, S., 1994. Removing the financial performance halo from Fortune's "most admired" companies. Academy of Management Journal, 37(5), pp.1347-1359.

Cabral, L., 2016. Media exposure and corporate reputation. Research in Economics, 70(4), pp.735740.

Campello, M., Graham, J.R. and Harvey, C.R., 2010. The real effects of financial constraints: Evidence from a financial crisis. Journal of Financial Economics, 97(3), pp.470-487. 
Cao, Y., Myers, L.A. and Omer, T.C., 2012. Does company reputation matter for financial reporting quality? Evidence from restatements. Contemporary Accounting Research, 29(3), pp.956-990.

Cao, Y., Myers, J.N., Myers, L.A. and Omer, T.C., 2015. Company reputation and the cost of equity capital. Review of Accounting Studies, 20(1), pp.42-81.

Cen, L., Dasgupta, S., Elkamhi, R. and Pungaliya, R.S., 2015. Reputation and loan contract terms: The role of principal customers. Review of Finance, 20(2), pp.501-533.

Chava, S. and Roberts, M.R., 2008. How does financing impact investment? The role of debt covenants. Journal of Finance, 63(5), pp.2085-2121.

Chava, S., Livdan, D. and Purnanandam, A., 2009. Do shareholder rights affect the cost of bank loans?. Review of Financial Studies, 22(8), pp.2973-3004.

Chen, Y., Ganesan, S. and Liu, Y., 2009. Does a firm's product-recall strategy affect its financial value? An examination of strategic alternatives during product-harm crises. Journal of Marketing, 73(6), pp.214-226.

Clarke, J., Khorana, A., Patel, A. and Rau, P.R., 2007. The impact of all-star analyst job changes on their coverage choices and investment banking deal flow. Journal of Financial Economics, 84(3), pp.713-737.

Cole, R.A., 1998. The importance of relationships to the availability of credit. Journal of Banking \& Finance, 22(6-8), pp.959-977.

Costello, A.M. and Wittenberg-Moerman, R.E.G.I.N.A., 2011. The impact of financial reporting quality on debt contracting: Evidence from internal control weakness reports. Journal of Accounting Research, 49(1), pp.97-136.

Cowen, A., Groysberg, B. and Healy, P., 2006. Which types of analyst firms are more optimistic?. Journal of Accounting and Economics, 41(1-2), pp.119-146.

Cremers, K.M., Nair, V.B. and Wei, C., 2007. Governance mechanisms and bond prices. Review of Financial Studies, 20(5), pp.1359-1388.

Denis, D.J. and Mihov, V.T., 2003. The choice among bank debt, non-bank private debt, and public debt: evidence from new corporate borrowings. Journal of Financial Economics, 70(1), pp.3-28.

Dennis, S., Nandy, D. and Sharpe, L.G., 2000. The determinants of contract terms in bank revolving credit agreements. Journal of Financial and Quantitative Analysis, 35(1), pp.87-110.

Diamond, D.W., 1984. Financial intermediation and delegated monitoring. Review of Economic Studies, 51(3), pp.393-414.

Diamond, D.W., 1989. Reputation acquisition in debt markets. Journal of Political Economy, 97(4), pp.828-862. 
Diamond, D.W., 1991. Monitoring and reputation: The choice between bank loans and directly placed debt. Journal of Political Economy, 99(4), pp.689-721.

Dierickx, I. and Cool, K., 1989. Asset stock accumulation and sustainability of competitive advantage. Management Science, 35(12), pp.1504-1511.

Fama, E.F., 1985. What's different about banks?. Journal of Monetary Economics, 15(1), pp.2939.

Fang, L. and Yasuda, A., 2011. Are stars' opinions worth more? Evidence from stock recommendations 1994-2009. Evidence from Stock Recommendations, 2009.

Fang, L., \& Yasuda, A. 2009. The effectiveness of reputation as a disciplinary device in sell-side research. Review of Financial Studies, 22, pp.3735-3777.

Faulkender, M. and Petersen, M.A., 2006. Does the source of capital affect capital structure?. Review of Financial Studies, 19(1), pp.45-79.

Fich, E.M., 2005. Are some outside directors better than others? Evidence from director appointments by Fortune 1000 firms. Journal of Business, 78(5), pp.1943-1972.

Fields, L.P., Fraser, D.R. and Subrahmanyam, A., 2012. Board quality and the cost of debt capital: The case of bank loans. Journal of Banking \& Finance, 36(5), pp.1536-1547.

Flanagan, D.J., O'shaughnessy, K.C. and Palmer, T.B., 2011. Re-assessing the relationship between the Fortune reputation data and financial performance: overwhelming influence or just a part of the puzzle?. Corporate Reputation Review, 14(1), pp.3-14.

Francis, J., LaFond, R., Olsson, P. and Schipper, K., 2005. The market pricing of accruals quality. Journal of Accounting and Economics, 39(2), pp.295-327.

Francis, J., LaFond, R., Olsson, P.M. and Schipper, K., 2004. Costs of equity and earnings attributes. Accounting Review, 79(4), pp.967-1010.

Gilson, S.C., 1990. Bankruptcy, boards, banks, and blockholders: Evidence on changes in corporate ownership and control when firms default. Journal of Financial Economics, 27(2), pp.355-387.

Goss, A. and Roberts, G.S., 2011. The impact of corporate social responsibility on the cost of bank loans. Journal of Banking \& Finance, 35(7), pp.1794-1810.

Graham, J.R., Li, S. and Qiu, J., 2008. Corporate misreporting and bank loan contracting. Journal of Financial Economics, 89(1), pp.44-61.

Haleblian, J.J., Pfarrer, M.D. and Kiley, J.T., 2017. High-Reputation firms and their differential acquisition behaviors. Strategic Management Journal, 38(11), pp.2237-2254.

Harford, J. and Uysal, V.B., 2014. Bond market access and investment. Journal of Financial Economics, 112(2), pp.147-163. 
Harford, J., 2003. Takeover bids and target directors' incentives: The impact of a bid on directors' wealth and board seats. Journal of Financial Economics, 69(1), pp.51-83.

Houston, J.F., Jiang, L., Lin, C. and Ma, Y., 2014. Political connections and the cost of bank loans. Journal of Accounting Research, 52(1), pp.193-243.

Jackson, A.R., 2005. Trade generation, reputation, and sell-side analysts. Journal of Finance, 60(2), pp.673-717.

Kaplan, S.N. and Reishus, D., 1990. Outside directorships and corporate performance. Journal of Financial Economics, 27(2), pp.389-410.

Kim, J.B., Song, B.Y. and Zhang, L., 2011. Internal control weakness and bank loan contracting: Evidence from SOX Section 404 disclosures. The Accounting Review, 86(4), pp.1157-1188.

Klock, M.S., Mansi, S.A. and Maxwell, W.F., 2005. Does corporate governance matter to bondholders?. Journal of Financial and Quantitative Analysis, 40(4), pp.693-719.

Koh, P.S., Qian, C. and Wang, H., 2014. Firm litigation risk and the insurance value of corporate social performance. Strategic Management Journal, 35(10), pp.1464-1482.

Lange, D., Lee, P.M. and Dai, Y., 2011. Organizational reputation: A review. Journal of Management, 37(1), pp.153-184.

Larcker, D.F. and Richardson, S.A., 2004. Fees paid to audit firms, accrual choices, and corporate governance. Journal of Accounting Research, 42(3), pp.625-658.

Leland, H.E. and Pyle, D.H., 1977. Informational asymmetries, financial structure, and financial intermediation. Journal of Finance, 32(2), pp.371-387.

Malenko, N. and Shen, Y., 2016. The role of proxy advisory firms: Evidence from a regressiondiscontinuity design. Review of Financial Studies, 29(12), pp.3394-3427.

Mansfield, E., Rapoport, J., Romeo, A., Wagner, S. and Beardsley, G., 1977. Social and private rates of return from industrial innovations. Quarterly Journal of Economics, 91(2), pp.221-240.

Merton, R.K. and Merton, R.K., 1968. Social Theory and Social Structure. Simon and Schuster.

Milgrom, P. and J. Roberts, 1982. Predation, reputation, and entry deterrence. Journal of Economic Theory, 27, pp.280-312.

Miller, G.S., 2006. The press as a watchdog for accounting fraud. Journal of Accounting Research, 44(5), pp.1001-1033.

Ortiz-Molina, H. and Phillips, G.M., 2014. Real asset illiquidity and the cost of capital. Journal of Financial and Quantitative Analysis, 49(1), pp.1-32.

Prilmeier, R., 2017. Why do loans contain covenants? Evidence from lending relationships. Journal of Financial Economics, 123(3), pp.558-579. 
Qiu, Y. and Shen, T., 2017. Organized labor and loan pricing: A regression discontinuity design analysis. Journal of Corporate Finance, 43, pp.407-428.

Rajan, R.G., 1992. Insiders and outsiders: The choice between informed and arm's-length debt. Journal of Finance, 47(4), pp.1367-1400.

Reed, R. and DeFillippi, R.J., 1990. Causal ambiguity, barriers to imitation, and sustainable competitive advantage. Academy of Management Review, 15(1), pp.88-102.

Roberts, G., \& Yuan, L. E., 2010. Does institutional ownership affect the cost of bank borrowing?. Journal of Economics and Business, 62(6), pp.604-626.

Roberts, P.W. and Dowling, G.R., 2002. Corporate reputation and sustained superior financial performance. Strategic Management Journal, 23(12), pp.1077-1093.

Servaes, H. and Tamayo, A., 2013. The impact of corporate social responsibility on firm value: The role of customer awareness. Management Science, 59(5), pp.1045-1061.

Stohs, M.H. and Mauer, D.C., 1996. The determinants of corporate debt maturity structure. Journal of Business, pp.279-312.

Strahan, P.E., 1999. Borrower risk and the price and nonprice terms of bank loans. Unpublished working paper, Banking Studies Function, Federal Reserve Bank of New York.

Sufi, A., 2009. Bank lines of credit in corporate finance: An empirical analysis. Review of Financial Studies, 22(3), pp.1057-1088.

Valta, P., 2012. Competition and the cost of debt. Journal of Financial Economics, 105(3), pp.661682.

Weigelt, K. and Camerer, C., 1988. Reputation and corporate strategy: A review of recent theory and applications. Strategic Management Journal, 9(5), pp.443-454.

Wilson, R., 1985. Reputations in games and markets. Game-Theoretic Models of Bargaining, pp.27-62.

Yermack, D., 2004. Remuneration, retention, and reputation incentives for outside directors. Journal of Finance, 59(5), pp.2281-2308. 